\title{
Domestic or Foreign Currency? Remittances and the Composition of Deposits and Loans
}

DOI:

10.1016/j.jebo.2019.01.023

\section{Document Version}

Accepted author manuscript

Link to publication record in Manchester Research Explorer

\section{Citation for published version (APA):}

Capasso, S., \& Neanidis, K. (2019). Domestic or Foreign Currency? Remittances and the Composition of Deposits and Loans. Journal of Economic Behavior \& Organization, 160, 168-183.

https://doi.org/10.1016/j.jebo.2019.01.023

\section{Published in:}

Journal of Economic Behavior \& Organization

\section{Citing this paper}

Please note that where the full-text provided on Manchester Research Explorer is the Author Accepted Manuscript or Proof version this may differ from the final Published version. If citing, it is advised that you check and use the publisher's definitive version.

\section{General rights}

Copyright and moral rights for the publications made accessible in the Research Explorer are retained by the authors and/or other copyright owners and it is a condition of accessing publications that users recognise and abide by the legal requirements associated with these rights.

\section{Takedown policy}

If you believe that this document breaches copyright please refer to the University of Manchester's Takedown Procedures [http://man.ac.uk/04Y6Bo] or contact uml.scholarlycommunications@manchester.ac.uk providing relevant details, so we can investigate your claim.

\section{OPEN ACCESS}




\title{
Domestic or Foreign Currency? \\ Remittances and the Composition of Deposits and Loans
}

\author{
Salvatore Capasso ${ }^{a}$ and Kyriakos C. Neanidis ${ }^{\mathrm{b}, *}$ \\ ${ }^{a}$ Institute for Studies on Mediterranean Societies (ISSM) - CNR and CSEF, Naples, Italy \\ ${ }^{\mathrm{b}}$ Economics, University of Manchester and Centre for Growth and Business Cycle Research, \\ Manchester, United Kingdom
}

\begin{abstract}
This paper investigates the effects of remittance receipts on the currency composition of deposits and loans in the home-country banking system. For this objective, we first develop a simple model that links remittance flows to the decisions of households and firms with regard to the optimal share of deposits and loans, respectively, held in the form of foreign currency. We, then, examine empirically the relevance of the theoretical predictions for fourteen Central and Eastern European countries over the last two decades. Both the theoretical and empirical findings underpin the importance of remittances for the currency composition of bank's balance sheets, pointing to a mismatch between deposits and loans: remittances raise the share of foreign currency loans whilst they reduce the share of foreign currency deposits.
\end{abstract}

JEL Classification: E44; F22; F24; F31; G11

Keywords: Remittances; foreign currency deposits; foreign currency loans; currency mismatch

*Corresponding author. Email address: kyriakos.neanidis@manchester.ac.uk 


\section{Introduction}

In recent years a vibrant literature has examined the role of remittances in influencing macroeconomic aggregates in recipient countries. The main reason for this wealth of studies is the observation that in most developing countries remittances represent an increasing share of total financial inflows. ${ }^{1}$ An aspect that has escaped the attention of researchers, however, is that, remittances typically accrue in recipient countries in the form of foreign currency, thus, having the potential to strongly influence the supply of and demand for foreign currency denominated assets. Due to this, it is plausible to envisage a link between a country's receipts of financial remittances and its share of financial holdings in foreign currency. This conjecture is even more plausible when one considers that financial transfers through remittances are commonly conducted in the form of currencies, such as, the US Dollar and the Euro, viewed as superior in comparison to domestic currencies. Following this line of thought, in this paper we draw a connection between financial remittances and the currency composition of deposits and loans in the recipient country, a link barely analyzed in the literature.

Foreign currency financial holdings, represented by the share of residents' financial holdings of assets and liabilities in foreign currency, has been explained through the dynamics of money demand and by means of network externalities and the costs of switching currencies, or, more recently, through the banks' portfolio optimization process. Interest in this subject draws from a broad consensus that foreign currency holdings can become a potential source of balance of payments and financial crises and pose a serious threat to macroeconomic and financial stability, especially in the presence of large exchange rate fluctuations. For this reason, it is important to examine whether, and to what extent, financial remittances influence the currency composition of banks' deposits and loans in remittance-recipient countries. In achieving this objective, the paper borrows the central argument from both the literature on financial remittances, which focuses on the idea that remittances play an insurance role for the recipient economy, and the literature that links foreign financial holdings to optimal asset portfolio adjustments. Importantly, the paper uses both theory and evidence in assessing the role of remittances for foreign financial holdings.

At the theoretical level, we develop a framework for studying the optimal choices of households and firms with regard to their holdings of assets and liabilities, respectively, in the form of domestic or foreign currency. By having in mind a developing economy, we focus on

\footnotetext{
${ }^{1}$ For example, World Bank figures show that for 2014 the share of personal remittances to GDP is 30.3 percent in the Kyrgyz Republic and 26.2 percent in Moldova, while the respective figures for the shares of foreign direct investment are 2.8 and 4.4 percent. Even though these two countries represent extreme cases, figures show that in most developing countries financial remittances represent a substantial fraction of international financial inflows.
} 
the behaviour of households and firms in a context in which financial development is relatively low and central bank behaviour is dictated by development policies rather than by short-run stabilization policies. An implication of this is that we choose to provide a stylized model that abstracts entirely from the decisions taken by both central and commercial banks. In the case of households, we depart from a framework proposed by Rapoport and Docquier (2006) in which remittances play an insurance role and depict an economy in which a household's member migrates abroad with the remaining member staying in the home country. The latter household member receives remittances from the migrating member, which consumes and saves in the form of domestic or foreign currency deposits. Under the assumption that domestic currency is riskier because of the possible sudden loss of purchasing power, households hold foreign deposits in order to hedge against this risk. The optimal share of foreign currency deposits depends on the relative expected rate of return on the two currencies, which, in turn, is affected by the volume of financial remittances entering the home economy. The model predicts that a positive shock to remittances in the form of foreign currency, increases the relative rate of return in domestic currency assets, leading to a lower share of foreign currency deposits. An analogous argument applies in the case of firms which require access to both domestic and foreign technology to produce their output. Assuming that the investment of firms in each technology requires access to loans, in domestic currency for the domestic technology and in foreign currency for the foreign technology, the optimal currency composition of loans dictates the optimal composition of technology. With the optimal composition of loans being a function of the relative borrowing costs between the two currencies, and the latter being determined by the volume of remittances entering the home economy (causing domestic currency loans to become more expensive), the model predicts a positive effect of financial remittances on the share of foreign currency loans. Putting these results together, an inflow of remittances causes an asymmetric effect on the banks' balance sheets, a lower share of foreign currency deposits and a higher share of foreign currency loans.

At the empirical level, we test the theoretical predictions of our model by employing a unique panel dataset of monthly observations. This includes fourteen transition economies in Central and Eastern Europe and the former Soviet Union over the period January 1993 to December 2009. We set an econometric specification that treats the shares of foreign currency deposits and loans separately, controlling for a host of their determinants as identified in the literature, to which we add a measure of financial remittance inflows. We find strong evidence in support of our theoretical illustrations: remittances have a significant and sizeable impact, negative on the share of foreign currency deposits and positive on the share of foreign currency 
loans. This evidence is based on an exhaustive array of robustness tests, including instrumentation of remittances, alternative regression specifications and different measures of remittance flows.

Our study sits at the intersection of two growing strands of the literature to which it makes contributions. First, we add to the existing evidence on the determinants of foreign currency deposits and loans. While the majority of the literature originally focused on the determinants of foreign currency deposits (see, for example, Ize and Yeyati 2003; Nicoló, Honohan, and Ize 2005; Yeyati 2006; Rennhack and Nozaki 2006; Vieira et al. 2012), more recent work has shifted attention to the asset side of banks' balance sheets (Barajas and Morales 2003; Arteta 2005; Honig 2009). The latter phenomenon has gained particular attention in Central and Eastern European countries due to their dynamic financial developments and expansion in foreign currency loans (Luca and Petrova 2008; Neanidis and Savva 2009; Neanidis 2010; Basso et al. 2011; Firdmuc et al. 2013; Kishor and Neanidis 2015). Our work acts complementary to all these studies, by being the first to offer another mechanism that promotes a mismatch in the shares of foreign currency deposits and loans: financial remittances. ${ }^{2}$ At the same time, differently from established frameworks that focus on the supply side and consider demand for foreign currency assets/liabilities as either exogenous or passively adjusting (i.e., the portfolio approach), our work focuses on the demand side, thus abstracting from banks' behaviour. The objective is to provide a different rationale for foreign currency holdings in a developing economy, highlighting the role of remittances. The strength of the effects being identified along with the channels via which they materialize, illustrate the importance of this mechanism.

Second, our study contributes to a broader literature that investigates the role of remittances in recipient countries. Much of the literature concerned with the effects of financial remittances has focused, amongst others, on the insurance role it provides against sudden and unexpected changes in income flows (Cox, Eser, and Jimenez 1998; Cox-Edwards and Ureta 2003; Mishra 2010; Balli and Rana 2015), on the recipient country's institutional quality (Abdih et al. 2012), poverty and inequality (Adams and Page 2005; Acosta et al. 2008), and economic growth (Fullenkamp et al. 2008; Barajas et al. 2009; Catrinescu et al. 2009; Giuliano and Ruiz-Arranz 2009). More recently, many empirical contributions have turned their attention to the effect of remittances on financial development, as measured by the ratio of total deposits and/or loans to GDP, and have identified an enhancing effect (Aggarwal et al. 2011;

\footnotetext{
${ }^{2}$ In one of their regressions, Firdmuc et al. (2013), based on household survey data from nine countries, were the first to show that the probability a household intends taking out a foreign currency loan is higher if it receives remittances. Their work, however, focuses on loans only, within a shorter time period and country sample.
} 
Demirgüç-Kunt et al. 2011; Cooray 2012). Although these latter studies are important in identifying a positive role of remittances for financial, and potentially economic, development, they have neglected the effect of remittances on the currency composition of deposits and loans. In our setting, the distinctive characteristic of the analysis is the focus on such currency composition effects. Doing so, allows us to draw conclusions about the broader impact of financial remittances.

The paper proceeds as follows. Section 2 sets out a simple model of remittances and foreign currency assets portfolio choices. The theory generates some sharp predictions, which guide the empirics that follow. Section 3 describes the empirical strategy and data used, while it also presents the empirical findings. Finally, Section 4 concludes.

\section{A simple model of remittances and foreign currency holdings}

Consider a poor economy populated by $N$ number of households and $M$ number of firms. Households are composed by two members who live for two periods. One household member lives in the home country, member $j$, while the other lives in a foreign country, member $m$. In the first period $m$ works and obtains a salary, $w^{m}$, which allocates in three activities: consumption, $c$, saving, $s$, and transferring resources home in the form of remittances, $T$. Member $j$ has no income and finances lifetime consumption through remittances received from member $m$. Thus, in the first period member $j$ receives transfers, consumes part of these resources and saves the remaining in order to finance consumption in the second period.

The home economy accepts two currencies for trade in consumption goods, the home currency, $h$, and the foreign currency, $f$. We distinguish the two currencies by their respective purchasing power risk. Purchasing power risk is modeled as in Li (1995), where the government confiscates with probability $1-\mu \quad(0 \leq \mu \leq 1)$ an equal proportion of home currency from all home residents. Thus, confiscation corresponds to a random loss of purchasing power. Following Craig and Waller (2004), we refer to this potential loss of purchasing power as currency risk. This formulation captures the idea that for some reason political, financial, or poor policymaking - the domestic currency in developing countries is prone to sudden losses of purchasing power, forcing agents to find ways to cover for this risk. ${ }^{3}$

We model the risk of sudden loss of purchasing power in $h$ by assuming a possible increase in the exogenous transaction cost agents pay when purchasing goods. More

\footnotetext{
${ }^{3}$ In its effects this cost is similar to the loss of purchasing power following a high inflation rate, caused by a public spending spree financed by money printing (see Holman and Neanidis 2006; Bose et al. 2007).
} 
specifically, we assume that the transaction cost of purchasing via $h$ can be either low (zero for convenience) with probability $0 \leq \mu \leq 1$, or high, $S_{h}$, with probability $1-\mu$. $S_{f}$, on the other hand, represents the transaction cost for purchasing via $f$ and is assumed to be fixed. We further assume that $S_{h}>S_{f}>0$.

\subsection{Households and foreign currency deposits}

Remittances are being sent by $m$ and received by $j$ in the form of foreign currency. These transfers can be employed by $j$ to purchase first period consumption goods, $c_{1}^{j}$, or can be saved in the form of deposits to finance second period consumption, $c_{2}^{j}$. Home country agents can save in the form of bank deposits either in home currency, $D$, or in foreign currency, $D^{*}$. The associated gross rates of return on deposits by currency are, respectively, $i$ and $i^{*}$.

We assume that currency can be converted into domestic or foreign at a fixed exchange rate equal to one. ${ }^{4}$ Recalling that holding home currency is risky in terms of loss of purchasing power, the net return per unit of currency saved in $D$ is

$$
\left\{\begin{array}{c}
R_{H}=i \quad \text { with prob } \mu \\
R_{L}=i-S_{h}
\end{array}\right.
$$

The net return per unit of currency saved in $D^{*}$ is instead $r=i^{*}-S_{f}$, where $R_{H}>r>R_{L}$. To ensure that both currencies are held in equilibrium, we assume that the expected net rate of return on domestic-currency deposits strictly exceeds the net rate of return on foreign-currency deposits

$$
\mu R_{H}+(1-\mu) R_{L}>r
$$

Letting $q=D^{*} /\left(D+D^{*}\right)$ denote the fraction of deposits held by $j$ in foreign currency, the per unit expected return on $j$ 's savings is given by $\mu\left[q r+(1-q) R_{H}\right]+(1-\mu)\left[q r+(1-q) R_{L}\right]$. Since we focus on the portfolio allocation problem of the agents living in the home country, we

\footnotetext{
${ }^{4}$ In order to simplify matters we assume that the exchange rate is fixed and that any adjustments, following a change in the relative supply between the two currencies, come through their rates of return. This highlights the role of money as a store of value in a model in which agents need money to transfer purchasing power across time and space. We also assume that central banks do not explicitly target interest rates, but rather allow them to adjust in response to external shocks.
} 
simplify the analysis by assuming that member $m$ can only save in a foreign asset delivering the interest rate, $i^{*}$.

The unit of the analysis is the entire household and, hence, decisions involving the optimal lifetime utility of both $m$ and $j$ are centralized at the household level (e.g., Lucas and Stark 1985; Faini 1994). The notion is that among family members there is a relationship of strong mutual financial support which is either rooted on altruism or based on some form of contractual arrangements: one member, for example, is helped in migrating with the promise of providing future support to the member staying home. As such, the household's objective is to maximize the expected lifetime utility of both the migrant, $V^{m}\left(c_{1}^{m} ; c_{2}^{m}\right)$, and the home-resident, $V^{j}\left(c_{1}^{j} ; c_{2}^{j}\right)$, by choosing their optimal lifetime consumption. Letting $\lambda$ represent the relative importance of $j$ 's wellbeing within the family, the household solves the following problem

$$
\begin{gathered}
\operatorname{Max} E\left[V^{m}\left(c_{1}^{m} ; c_{2}^{m}\right)\right]+\lambda E\left[V^{j}\left(c_{1}^{j} ; c_{2}^{j}\right)\right] \\
\text { s.t. } \quad c_{1}^{m}=w^{m}-T-s^{m}, \quad c_{2}^{m}=s^{m}\left(1+i^{*}\right) \\
c_{1}^{j}=T-s^{j}, c_{2}^{j}=s^{j}\left\{\mu\left[q r+(1-q) R_{H}\right]+(1-\mu)\left[q r+(1-q) R_{L}\right]\right\} \\
T \geq 0,0<q<1, c_{t}^{i} \geq 0 \forall i=m, j \text { and } t=1,2, \text { and condition }(1),
\end{gathered}
$$

where $s^{m}$ and $s^{j}$ denote the savings of family members $m$ and $j$ respectively. To simplify matters, and obtain explicit values for all choice variables, we assume the utility function of both members to be logarithmic in their consumption, so the household's problem can be rewritten in the following way

$$
\begin{aligned}
& \operatorname{Max}\left\{\ln \left(w^{m}-T-s^{m}\right)+\ln s^{m}\left(1+i^{*}\right)+\right. \\
& \left.+\lambda\left\{\ln \left(c_{1}^{j}\right)+\mu \ln \left[q r+(1-q) R_{H}\right]\left(T-c_{1}^{j}\right)+(1-\mu) \ln \left[q r+(1-q) R_{L}\right]\left(T-c_{1}^{j}\right)\right\}\right\} \\
& \quad \text { s.t. } \quad T \geq 0,0<q<1, c_{t}^{i} \geq 0 \forall i=m, j \text { and } t=1,2, \text { and condition (1). }
\end{aligned}
$$

Solving the optimization problem delivers the following values for $T, s^{m}, c_{1}^{j}$ and $q$ :

$$
T=\frac{2 \lambda w^{m}}{1+2 \lambda}
$$




$$
\begin{gathered}
s^{m}=\frac{w^{m}}{2(1+2 \lambda)}, \\
c_{1}^{j}=\frac{\lambda w^{m}}{1+2 \lambda}, \text { and } \\
q=\frac{(1-\mu)\left(r-R_{L}\right) R_{H}-\mu\left(R_{H}-r\right) R_{L}}{\left(R_{H}-r\right)\left(r-R_{L}\right)} .
\end{gathered}
$$

As expected, the amount of remittances each member $m$ transfers back home, shown in equation (4), depends positively on his own first period income, $w^{m}$, and on the bargaining power of member $h$ within the household, $\lambda$. Further, due to the assumption of a logarithmic utility function, equations (5) and (6) indicate that each of the two family members, $h$ and $m$, consumes and saves in the first period an equal amount of resources. This amount, however, is different for each member, i.e., $s^{j}=\frac{\lambda w^{m}}{1+2 \lambda}=c_{1}^{j}$ and $s^{m}=\frac{w^{m}}{2(1+2 \lambda)}=c_{1}^{m}$. Since the only source of income for both members is $m$ 's first period wage, the latter affects positively the levels of consumption and savings of both agents.

In addition to deciding the optimal amount of transfers, consumption and savings per member, households also choose the optimal allocation of savings in the remittance-recipient country between domestic and foreign currency deposits, $q$, shown in equation (7). It is easy to show (see the Appendix) that the restriction $R_{H}>r>R_{L}$ implies a feasible solution for $q$, i.e., $q \in(0,1)$, provided $\mu$ is upper and lower bounded. Further, substituting for $R_{H}, R_{L}$ and $r$, equation (7) can be written as

$$
q=\frac{\left(i^{*}-i+S_{h}-S_{f}\right) i-\mu\left(i^{*}-S_{f}\right) S_{h}}{\left(i-i^{*}+S_{f}\right)\left(i^{*}-i+S_{h}-S_{f}\right)}
$$

Equation (8) shows that as one might expect, $q$ depends on the expected relative returns between the two currencies. This yields

Proposition 1. The optimal share of remittances saved in foreign currency deposits, $q$, is a decreasing function of the expected rate of return on home currency as determined by $i$ and $\mu$, and an increasing function of the expected rate of return on foreign currency, $i *$ 
The expected rate of return on each currency depends not only on the interest rates, $i$ and $i^{*}$, but also on factors influencing the expected purchasing power cost, such as $\mu$. From equation (8), it is easy to infer that a decrease in the risk of purchasing power loss associated with the domestic currency, i.e., a higher $\mu$, reduces the share of remittances saved in foreign currency deposits, $q$. The effect of the rate of return on each currency is not as straightforward. Nevertheless, a more formal analysis in the Appendix shows that $q$ declines in response to higher $i$, while it rises in response to higher $i^{*}$, confirming Proposition 1.

Intuitively, these findings have the following interpretation. Since member $j$ derives second period income out of the savings of the first-period remittances he receives, and since the return on domestic currency is risky, households optimally choose to hold part of saved remittances in foreign currency to cover for the risk of sudden loss of purchasing power in domestic currency. Hence, in this framework, holdings of foreign-currency deposits are the result of the household's optimal portfolio allocation of remittances when the two available assets are risky. Equation (8), however, does not reveal any relationship between aggregate remittances and foreign currency deposits, of interest to us, a matter to which we will be returning below.

\subsection{Firms and foreign currency loans}

Domestic firms employ a production function in which a technology available in the home country can be combined with a technology only available abroad (see, for example, Blackburn et al. 2005 for a similar treatment of output production). To purchase these technologies, a firm needs to access external resources through a loan. The home technology can be obtained through a loan in home currency, $l$, while the foreign technology requires a loan in foreign currency, $l^{*}$. We assume that these technologies are (i) complements, (ii) can be combined continuously, and (iii) there is one-to-one relationship between the amount of loans and the units of technology, so that we use the loans indicator to represent units of technology. To simplify matters further, we assume that the two technologies combine in a Cobb-Douglass

form $y=\beta l^{\alpha} l^{(1-\alpha)}$ in which $\alpha$ and $(1-\alpha)$ represent, respectively, the contribution of the home and foreign technology in output production. Production requires one period and the timing of the investment is as follows. At time $t$, the firm chooses the optimal combination of home and foreign technology and applies correspondingly for a loan in home or foreign currency to implement the technologies. At time $t+1$, the firm obtains output from which it repays the 
loans. ${ }^{5}$ By assuming that the interest rate charged on both the domestic and foreign currency loans is a proportion $\gamma>1$ of the interest rate offered on deposits, reflecting the size of banking intermediation costs, and normalizing the price of each unit of output to one, each firm solves the following profit maximization problem

$$
\operatorname{Max} \beta l^{\alpha} l^{*(1-\alpha)}-\left(1+\gamma i^{*}-S_{f}\right) l^{*}-\left[\mu(1+\gamma i)+(1-\mu)\left(1+\gamma i-S_{h}\right)\right] l
$$

where the net cost of credit on each type of loan depends on the transaction costs associated to each currency. ${ }^{6}$ The solution to the above problem gives rise to the following optimal share of foreign technology and, subsequently, to the optimal share of foreign currency loans to total loans

$$
z \equiv \frac{l^{*}}{l+l^{*}}=\frac{\left[1+\gamma i-(1-\mu) S_{h}\right](1-\alpha)}{\left(1+\gamma i^{*}-S_{f}\right) \alpha+\left[1+\gamma i-(1-\mu) S_{h}\right](1-\alpha)},
$$

which lies in the range $(0,1)$.

Analogously to households, firms located in the home country face an optimal resource allocation problem. A more intense use of one technology, and correspondingly of one form of financing, involves a different return in output production but also a different expected borrowing cost. Borrowing costs, in turn, are influenced by the expected rate of return to each currency. Each firm trades off at the margin the expected gains by the use of one technology with the respective expected borrowing costs. Optimization delivers the following proposition

Proposition 2. The optimal share of foreign currency loans, $z$, is an increasing function of the expected borrowing cost in domestic currency, $i$, and $\mu$, and a decreasing function of the expected borrowing cost in foreign currency, $i^{*}$.

Differentiating equation (10), it is easy to verify that $\frac{\partial z}{\partial x}>0$ where $x=i, \mu$ and $\frac{\partial z}{\partial i^{*}}<0$, which prove Proposition 2 (see the Appendix). This result is not surprising since it entails that each firm will employ more intensively the foreign technology and, correspondingly, will demand a larger share of foreign currency loans, $z$, when the borrowing costs related to foreign

\footnotetext{
${ }^{5}$ This line of events means that a firm cannot borrow in home currency to purchase a foreign technology. The fact that the exchange rate is fixed and equal to one, allows firms to purchase foreign technology without the fear of engaging in exchange rate risk.

${ }^{6}$ An implicit assumption is that the transaction cost for purchasing technology goods is the same as that of purchasing consumption goods.
} 
loans are lower (a decrease in $i^{*}$ ). The opposite occurs when the relative expected borrowing costs in domestic currency decline (a decrease in $i$, and $\mu$ ). For example, a higher probability of lower domestic currency transaction cost, a lower $\mu$, decreases the expected cost of financing in home currency and, hence, makes optimal a more intense use of the home technology: the share of loan in foreign currency decreases.

Having established the determinants of foreign currency borrowing at the individual firm level, we now turn to explaining the association between aggregate remittances and the currency denomination of both deposits and loans in the remittance-recipient country.

\subsection{Remittances and currency composition of deposits and loans}

Equation (8) describes the optimal allocation of the household's saved remittances between domestic and foreign currency deposits. As shown, the optimal share of remittances held in foreign currency deposits depends on the relative expected rate of return between foreign and domestic currency but it does not depend on the level of remittances. Similarly, equation (10) dictates that the share of foreign currency loans demanded by each firm depends on the relative borrowing cost associated with the home and foreign currency but is independent of the absolute level of remittances. Although this is the case at the level of the individual household and firm, one can argue that at the economy-wide level aggregate remittances may affect the relative return/cost of domestic and foreign currency and, hence, the share of both foreign currency deposits and loans.

In particular, if one assumes that the relative gross rate of return on the two currencies, $i / i^{*}$, is a function of the aggregate amount of remittances, via a supply side effect, then aggregate remittances will also affect both the share of deposits in foreign currency, $q$, and the share of loans in foreign currency, $z$. The underlying intuition is that for a given domestic money supply, a positive exogenous shock to the aggregate level of remittances will positively affect the relative rate of return between domestic and foreign currency, $i / i^{*}$, and in this way change the optimal choice of individual households and firms so that $q$ drops and $z$ rises. More formally, let $\tilde{T}=N T$ be the aggregate supply of remittances in the economy at each point in time and assume that the relative interest rate of the two currencies is a positive function of $\tilde{T}$, i.e., $i / i^{*}=f(\tilde{T})$ with $\partial f(\tilde{T}) / \partial \tilde{T}>0$. This implies that a positive shock to aggregate remittances reduces the relative rate of return of foreign-currency holdings given that remittances enter the home economy in the form of foreign currency, and, hence, reduces the households' optimal size of $q$. In this way, the model predicts that remittances are negatively 
associated with the share of deposits in foreign currency. In other words, more remittances lead to lower holdings of foreign currency deposits.

Similar arguments can be applied to the demand for foreign loans. Firms' optimal composition of loans in foreign currency, $z$, depends on the relative gross interest rates charged on loans offered in the two currencies. Hence, following a positive aggregate shock to the level of remittances, the aggregate supply of foreign currency increases and so does the cost of borrowing in domestic currency, since $i / i^{*}$ rises. The increase in $i / i^{*}$ makes borrowing in foreign currency cheaper and more appealing to firms. This, in turn, leads to a higher $z$. Hence, the model predicts that a greater level of remittances induce a higher share of loans in foreign currency. It is useful to summarize these results with the following proposition ${ }^{7}$

Proposition 3. An increase in remittances in the recipient economy reduces the share of foreign currency deposits, $q$, and raises the share of foreign currency loans, $z$.

Proposition 3 draws from the earlier two propositions and a formal proof appears in the Appendix. Proposition 3 implies that the model predicts an asymmetric effect of remittances between foreign currency deposits and loans, leading to a mismatch between the two on the banking sector's balance sheets. A literature has already identified the dire consequences of such mismatch (e.g., Neanidis 2010; Kishor and Neanidis 2015). Our simple model further illustrates this phenomenon with remittances playing a central role in its transmission. Next we turn to an empirical investigation of the theoretical predictions of the model.

\section{Empirical analysis}

This section describes the specification, data, and estimation strategy that we use to explore the issues and hypotheses raised above. It also presents the empirical findings based on a series of regressions and robustness tests.

\subsection{Specification}

The strategy is to estimate a series of panel regressions of the general form

\footnotetext{
${ }^{7}$ It is important to stress that these results hold by entirely abstracting from possible changes in the exchange rate between the two currencies. If we were to consider such changes, as more foreign currency enters the home country due to remittances, its value diminishes against that of the domestic currency, so that households optimally reduce their foreign-currency deposits and firms optimally increase their holdings of the now cheaper foreign currency loans. This is yet another channel that reinforces the negative effect of remittances on foreign currency deposits and the positive effect on the share of foreign currency loans.
} 


$$
Y_{i, t}=\alpha+\beta R_{i, t}+\gamma^{\prime} X_{i, t}+\mu_{i}+\lambda_{t}+\varepsilon_{i, t}
$$

where $Y_{i, t}$ is either the share of foreign currency deposits (FCD) to the total amount of deposits of residents at domestic banks, or the share of foreign currency loans (FCL) to the total amount of loans of domestic banks to residents, for country $i$ in period $t$. $R_{i, t}$ represents the amount of remittances received, $X_{i, t}$ is a vector of controls, and $\mu_{i}, \lambda_{t}$ and $\varepsilon_{i, t}$ are respectively countryfixed effects, time-fixed effects, and the error term. Attention focuses on the parameter $\beta$, which captures the effect of remittances on the recipient countries' shares of foreign currency deposits or loans. According to the preceding theoretical analysis, the sign for this estimated coefficient is expected to be negative for the share of foreign currency deposits and positive for the share of loans.

The controls in $X$ are those commonly included in regressions explaining the shares of FCD and FCL (see De Nicoló et al. 2005; Yeyati 2006; Vieira et al. 2012). First, we include the rates of inflation and depreciation as these macroeconomic variables by changing the value of the domestic currency can change the value, and attractiveness, of foreign currency deposits and loans (see Savastano 1996; Arteta 2005). Second, we include the minimum variance portfolio (MVP) dollar share which captures movements in the second moments of inflation relative to that of real depreciation (Ize and Levy-Yeyati 2003). Third, we include an indicator of international financial integration as a measure of financial openness that makes the domestic banking and financial sector more accessible to the rest of the world (Luca and Petrova 2008; Honig 2009; Neanidis and Savva 2009). Fourth, we include a set of three dummy variables controlling for regulatory, institutional and high-FCD/FCL environments. These are (i) a dummy that proxies for restrictions on holding deposits (loans) in foreign currency (Arteta, 2005), (ii) a dummy associated with a country's European Union (EU) admission process (Neanidis, 2010), and (iii) a dummy that controls for periods and countries that experience high shares of FCD and FCL (Neanidis and Savva, 2009) as an indicator of time and country persistence in foreign currency holdings. Finally, we add two variables specific to the regression of foreign currency loans. The first is the share of FCD, the expectation being that banks lend more in foreign currency as they receive more foreign currency deposits in a way to limit their exchange rate risk (Luca and Petrova, 2008; Neanidis and Savva, 2009). The second is net foreign assets: net foreign assets are an alternative to bank holdings of FCL, so that 
higher net foreign assets limit the need of banks for foreign currency lending. Details on the exact definition of all these variables can be found in the Appendix Table A. ${ }^{8}$

\subsection{Data}

The sample comprises a unique panel dataset of monthly observations for 14 transition economies located in Central and Eastern Europe and the former Soviet Union. ${ }^{9}$ The selection of the countries has been guided by two principles: (i) a long series of monthly shares of FCD and FCL, and (ii) the presence of monthly observations for remittances. Only 14 transition economies satisfy these two principles. The sources of these data, as indicated in Appendix Table A, are primarily reports from National Central Banks, the former from monetary and financial statistics and the latter from balance of payments statistics. The sample period coverage varies across countries, mainly due to the availability of remittances data, starting as early as January 1993 (for Slovenia and Turkey) and extending all the way to December 2009 (for all countries). ${ }^{10}$ We do not use data post 2009 as we wish to abstain from the abnormal period during the Great Recession.

Table 1 summarizes the data set, including those variables used in the robustness analysis. The average ratio of both FCD and FCL is high, $43 \%$ and $40 \%$ respectively, with substantial variation across countries and across time. ${ }^{11}$ For example, there are countries, such as Armenia, Bulgaria, Georgia, and the Kyrgyz Republic, with relatively high levels of both FCD and FCL of well over 50\%, in contrast to the Czech Republic and Slovak Republic that experience low levels of about $10 \%$. There are also countries where the shares of both foreign currency deposits and loans exhibit high variation over time (Armenia, Georgia, Turkey), whereas in others the variation is small (Macedonia FYR and Moldova). These observations

\footnotetext{
${ }^{8}$ It is important to note that we exclude from vector $X$ the ratio of the interest rates between domestic and foreign currency deposits and loans $(i / i *)$. Although relative interest rates (or their differences) for both deposits and loans are used to test the departure from uncovered interest rate parity (Basso et al., 2011) and are considered an important driving factor of foreign currency holdings by both depositors and borrowers, we do not control for this variable due to the mechanism of transmission of the effect of remittances on the shares of FCD and FCL identified in our theoretical model. As the impact of remittances is facilitated via this particular channel, we need to exclude this variable from the control list. We do include however some further controls in our robustness tests below.

${ }_{9}$ The countries are Armenia, Bulgaria, Czech Republic, Georgia, Kyrgyz Republic, Latvia, Lithuania, Macedonia, FYR, Moldova, Romania, Serbia, Slovak Republic, Slovenia, and Turkey.

10 The Slovak Republic and Slovenia represent exceptions since the end-of-period coverage is at the end of 2008 and 2006, respectively, as a way of avoiding the periods after which these countries formally adopted the euro as their legal tender.

${ }^{11}$ Although the number of observations in the data is similar for FCD and FCL, the former series includes one country less, Romania. This indicates that data on FCD are more heavily populated across countries compared to those of FCL.
} 
show that the dataset includes countries with varying experiences in their shares of foreign currency deposits and loans.

Following the World Bank and the standard practice in the literature, we define aggregate remittances as the sum of workers' remittances and compensation of employees. ${ }^{12}$ We use the sum of these two variables because for most of the countries in our sample, there is no clear distinction between them. In addition, for the few countries that there is a distinction, data are available for only one of the two variables (worker's remittances for Albania, Georgia and Moldova, while employees' compensation for the Czech Rep. and Latvia). ${ }^{13}$ Further, the literature offers various ways for introducing remittances in a regression analysis, expressed in per capita terms, real per capita values, or scaled by recipient country GDP (see Adams 2009; Aggarwal et al. 2011). To start with, we scale aggregate remittances by the recipient country's population and obtain remittances per capita, although we also experiment with other suggested measures. Table 1 shows average remittances per capita of 8.6 U.S. dollars with high variation, as indicated by the standard deviation and the minimum and maximum values in the sample. Figure 1 further indicates the significant time variation in remittances per capita, reflecting the worldwide upward trend, especially in the most recent years. ${ }^{14}$

The remaining control variables, which mainly consist of macroeconomic and financial data, are primarily drawn from the IMF International Financial Statistics and are available at monthly frequency, except for the index of international financial integration (Lane and MilesiFerretti 2007) which is available at the annual level. Similarly, some of the variables considered in the robustness analysis are at the annual level, while the coverage of corruption data from Transparency International is less complete than for other variables. The sample size is thus reduced by about one tenth in regressions including corruption, so we simply illustrate its impact in one regression, providing some reassurance that any bias from its omission when using the much larger dataset is immaterial.

\subsection{Estimation}

We estimate equation (11) with a variety of techniques. We start with pooled OLS where robust standard errors are adjusted for heteroskedasticity and serial correlation. We next

\footnotetext{
12 We have checked the consistency and accuracy of the monthly remittances data in our set, drawn from individual-country Central Bank reports, against the annual data collected by the World Bank.

${ }^{13}$ Later we offer a way to control for this inconsistency in the measurement of remittances across countries with a robustness test that involves excluding from the sample the five countries for which remittances is not the sum of workers' remittances and compensation of employees.

${ }^{14}$ Higher remittances per capita represent a positive shock to the aggregate amount of remittances so long as they rise across time. Figure 1 supports this view, allowing the measure of remittances per capita used in the empirical analysis to be consistent with the use of aggregate remittances in the theoretical modelling.
} 
apply feasible generalized least squares (FGLS) that control for panel heteroskedasticity and panel specific autocorrelation, and the fixed-effects estimator that controls for unobserved country- and time-specific effects. Our preferred approach, however, involves estimation by an instrumental variable technique: the two-step GMM estimator that generates efficient estimates of the coefficients as well as consistent estimates of the standard errors robust to both arbitrary heteroskedasticity and arbitrary intragroup correlation. The advantage of this technique is that it addresses the potential endogeneity of our variable of interest, remittances, on the shares of FCD and FCL.

There are two plausible reasons for suffering from reverse causality. First, a country with an already established high degree of foreign currency holdings might make the additional receipt of such assets easier. In other words, increased popularity of foreign currency accounts might lead to greater availability and lower costs for remittance services, which, in turn, raise the flow of remittances. A second source of endogeneity could be more serious. A high share of foreign currency deposits and loans in the banking sector may cause low economic growth (see Benhima 2011) and a lack of economic development, or both may be related to some omitted third factor. The lack of development, in turn, might lead to out-migration and, subsequently, higher remittance flows. That is, our regression may be mis-specified because we lack a control for countries with "bleak futures.",

We address this issue by instrumenting for remittances using two variables that have been established as important determinants of remittances in the literature. The first is the share of outward migrants in the total domestic population (Adams Jr. and Page 2005), calculated as the sum of migrants from each labor-exporting country living in the OECD (and selected nonOECD) members, divided by the population of the country of origin. ${ }^{16}$ The second instrument is remittances per capita for all other recipient countries located in the same region (Fullenkamp et al. 2008; Combes and Ebeke 2011). This amounts to excluding from total remittances per capita the values for the country in question. Our instrument set must satisfy the conditions of relevance and exogeneity. Put differently, the instruments must be correlated with remittances, and their effect on foreign currency holdings must operate solely through its effect on remittances. We now discuss each condition in turn.

\footnotetext{
15 This is a possibility, although we do our best to control for variables that can jointly influence the share of foreign currency holdings and remittances, such as inflation rates and changes in exchange rates.

${ }^{16}$ We focus on OECD members as this is the only source of consistent annual data of migration flows for both country of origin and destination. Most likely, however, these figures underestimate the actual number of international migrants because they do not include the number of illegal migrants working in the country of residence.
} 
Our instruments are relevant as long as they influence the amount of remittances send at the country of origin. Obviously, the number of migrants leaving a country, as a fraction of those staying back, in search of a better future abroad contributes to higher remittance flows. The objectives of the flows may differ, but typically include the improvement of the household welfare back home and serve as a consumption-smoothing mechanism in the context of negative external shocks. A direct implication of this is that remittances allow increases in savings and the accumulation of assets, including deposits in foreign currency. Turning to regional remittances, as indicated by Fullenkamp et al. (2008), they capture the effect of systematic changes in the microeconomic determinants of remittances and the general trends in remittances at the regional level, including changes in transaction costs. They, thus, offer a channel via which remittances to a country are driven by factors unrelated to developments in this specific country.

Consider next exogeneity, which requires that our instruments are not correlated with the shares of FCD and FCL after controlling for remittances and all additional second-stage regressors. It is difficult to envision a scenario where a country's outward migrants can dictate decisions to their family at the country of origin regarding the currency composition of the family's deposits and loans unless they contribute to the family finances directly, i.e., via remittances. This implies that outward migration should not have an effect on a country's foreign currency holdings other than through remittance flows. Similarly, regional remittances capture the effects of regional reductions in transactions costs and abstract from any idiosyncratic changes in the determinants of remittances. In this way, they are free of a direct causal link with other domestic macroeconomic and policy variables that can influence the shares of foreign currency holdings.

\subsection{Results}

The empirical analysis begins with core results on the effects of remittances on the shares of FCD and FCL based on all four different estimation techniques. It then focuses on the GMM technique and examines different regression specifications before exploring the use of alternative measures for remittances and some additional sensitivity tests.

The first set of results is reported in Table 2. The estimates in columns (1)-(6) treat remittances per capita as an exogenous determinant of the ratios of foreign currency loans and deposits, while the final two columns relax this assumption. Columns (1)-(2) report results for the pooled OLS regression. The estimated coefficient on remittances per capita is negative and strongly significant for both types of foreign currency accounts. Using feasible GLS estimation 
in columns (3)-(4) leads to notably smaller coefficients, in absolute size, but still significant at an acceptable level. It is only when we control for country-level fixed effects that the effect on the share of foreign currency loans switches sign to positive, while it retains its negative coefficient for the share of foreign currency deposits. This suggests that within-country variation in both remittances and the shares of foreign currency holdings should not be neglected. It is because of this, and for the potential to address endogeneity issues, that we prefer GMM estimation.

Columns (7)-(8) present the GMM results. Starting with the first-stage regressions, reported in the lower panel of the table, they demonstrate that our set of instruments is indeed capable of explaining a large fraction of the variation in our endogenous variable. In both regressions, the $\mathrm{F}$ test easily rejects the null hypothesis of no effect from the instrument set, and the fraction of variation explained by our instruments is 0.5 for the share of FCD and above 0.6 for the ratio of FCL. Further, the instruments have the expected effect on our endogenous variable, with both the share of outward migrants and regional remittances per capita confirming our priors regarding their positive impact on individual-country remittances per capita.

Turning to the second-stage results, findings establish the asymmetric impact of remittance flows per capita on foreign currency holdings: a strong negative effect on the share of FCD and a strong positive effect on the share of FCL. This finding is a strong indication in support of the predictions of the theoretical model outlined above. Compared to earlier regressions, the estimated effect is more than twice as large in absolute magnitude and statistically significant at least at the 5\% level. This larger effect implies a downward bias in our earlier estimates when not controlling for the endogeneity of remittances. Using these coefficient estimates implies that doubling the average amount of remittances per capita, from $\$ 8.63$ to $\$ 17.26$, decreases the share of foreign currency deposits by 0.7 percentage points and simultaneously raises the share of foreign currency loans by 0.4 percentage points. Admittedly, the size of these effects is small, but so is the size of average per capita remittances. ${ }^{17}$

Standard specification tests indicate the validity of the instruments. In addition to the high $\mathrm{F}$ statistics reported in the first-stage regressions, we now find that both the Kleibergen and Paap (2006) LM and F tests reject the null hypotheses of underidentification and weak identification, respectively, of the excluded instruments. Further, we use the Hansen overidentification $J$ test to examine whether the instruments are orthogonal to the error process

\footnotetext{
${ }^{17}$ We will return to this matter when using alternative measures of remittances later in the analysis. Obviously, the way remittances are measured by influence the quantitative magnitude of the effect.
} 
in the regression, i.e., whether the instruments explain foreign currency holdings beyond their effects on remittances per capita. The high p-value suggests that the instruments do not reject the overidentification test, meaning that they are indeed jointly valid.

The coefficient estimates of the control variables are pretty consistent across estimation techniques and largely confirm the findings established in the literature. For both the shares of deposits and loans in foreign currency, higher foreign currency holdings are induced (i) in environments already characterized by significant holdings of foreign currency suggesting persistence or hysteresis, (ii) by higher MVP dollar share, (iii) when the domestic currency loses its value due to depreciation, and (iv) by greater international financial integration. In addition, higher inflation causes a shift toward FCL (but not FCD). In contrast, both FCD and FCL shares are reduced because of legal restrictions on the holdings of foreign currency accounts, except for the GMM regression, while a country's formal association with the EU reduces the share of FCD (with no effect on FCL). Finally, the additional two controls in the regressions of FCL shares, the share of FCD and the net foreign assets, are strongly significant with the former being positive and the latter negative, both confirming our priors. In general, the instrumental variable approach appears to be supportive of our theoretical story, in that greater remittance flows are a significant explanatory factor of shares in FCD and FCL in the remittance-recipient countries with effects being opposite in direction.

To establish the robustness of our findings, we conduct the following three exercises. First, we expand the list of control variables to consider the possibility of omission variables bias. Second, we use alternative measures of remittances and, by so doing, calculate the magnitude of their economic effect. Third, we conduct some additional sensitivity checks. In Table 3, columns (1)-(2) present results by adding a break-down of the EU dummy in its three distinct stages of the EU admission process-beginning of the EU process, confirmation of decision to join the EU, and eventual EU membership (details appear in Appendix Table A). Each of the following pair of columns adds respectively a dummy for forward market liberalization (Luca and Petrova, 2008), an index of asymmetry of exchange rate movements (Rennhack and Nozaki 2006), an index of exchange rate intervention to control for different exchange rate regimes (Barajas and Morales Bueno 2003), and, finally, a measure of institutional quality proxied by corruption (De Nicoló et al., 2005).

In all cases, the effects of our interest are retained both in terms of the sign and magnitude of remittances per capita. The only exception, in terms of the magnitude, appears in the final two columns when corruption is added as control, possibly due to the loss of observations. In terms of the effects of the additional controls, every stage of the EU admission 
process reduces the share of deposits in foreign currency and raises the share of loans in foreign currency, corroborating the findings in Neanidis (2010). The presence of a functional forward market or of asymmetric exchange rate movements do not affect holdings in foreign currency, suggesting the lack of importance in currency hedging mechanisms and the absence of a bias towards currency depreciation for both depositors and borrowers. Exchange rate intervention toward a harder peg discourages FCD and encourages FCL, in line with that both depositors and borrowers consider themselves immune to exchange rate fluctuations as authorities have an explicit commitment to defend the peg. Finally, a better institutional environment, proxied by the absence or the control of corruption, reduces the share of FCL while it has no effect on that of FCD.

Table 4 reports results when using different measures of remittances. These are now real per capita remittances in columns (1)-(2), remittances as fractions of total deposits or loans in columns (3)-(4), and remittances normalized by GDP in columns (5)-(6). It is important that our findings as to the asymmetric effect on foreign currency assets carry over to the use of these different remittance measures. If we compare the estimated coefficients for the different measures of remittance flows, we note that the magnitude of the effects is greater than those in the previous tables. For example, a 10 percentage point increase in real remittances per capita decreases the share of FCD by 8 percentage points and increases the fraction of FCL by 4.5 percentage points. These are non-negligible effects with the magnitude of the effect on FCL being in line with Firdmuc et al. (2013) who estimate the probability that a remittance-recipient household takes a foreign currency loan to be higher by 5 percentage points compared to a nonremittance-receiving household (based on recent household survey data for 9 Central and Eastern European Countries). Using the coefficient estimates of remittances when expressed as fractions of deposits, loans, or GDP leads to even larger quantitative effects on foreign currency holdings.

Last, we conduct three further robustness tests, the results of which are not reported but are available upon request. We first limit the sample period to the post-1996 years to control for the early abnormal transition years experienced by participants in the foreign currency market in the countries of our sample since they were more favorable to foreign currency holdings due to the uncertainty that surrounded the success of market oriented policies. Next, we test whether our findings are a consequence of outlier observations by dropping a country each time from the sample. We then exclude the countries in our sample for which the measure of remittances does not correspond to the sum of workers' remittances and compensation of 
employees, but only to one of these (Albania, the Czech Republic, Georgia, Latvia, Moldova). Our findings survive these additional considerations, providing further credibility to our results.

\section{Conclusions}

Numerous studies have identified the importance of remittances for various macroeconomic indicators in the country of remitters' origin, with many recent studies focusing on one such aspect: the contribution of remittances to financial development by having found that it raises both total deposits and loans (as fractions of GDP). There is, however, no analysis that examines the effect of remittances on the composition of deposits and loans between domestic and foreign currency. This is an important consideration given that high shares of foreign currency holdings have been associated with balance of payments and financial crises and overall macroeconomic instability, especially in the presence of exchange rate swings. This paper takes the literature forward by tackling this issue, exploring the role of remittances for the currency composition of bank assets and liabilities in remittance-recipient countries.

At the theoretical level, we develop a simple model that links remittance inflows to the decisions of households and firms with regard to the optimal fractions of holdings in deposits and loans in terms of their currency. At the individual level, decisions are guided by the expected relative rate of return and relative cost of borrowing in the two currencies. At the aggregate level, this allows a supply side effect to materialize: greater remittance inflows, by changing the relative rate of return versus borrowing in the two currencies, causes a shift toward (cheaper) foreign currency loans and away from (lower-return) foreign currency deposits. This argument implies that both household-depositors and firm-borrowers adjust optimally their currency portfolio of assets and liabilities, respectively, in response to the inflow of remittances so as to take advantage of the resulting lower currency risk: in domestic currency for depositors and in foreign currency for borrowers. Ultimately, at the aggregate level, it is this lower currency risk from the perspective of depositors and borrowers that drives the wedge in the currency portfolios of banks.

Our empirical results present convincing evidence that the above theoretical findings hold in practice. Controlling for a large number of determinants of foreign currency holdings found in the literature, we find that remittance flows is a powerful explanatory factor of such holdings. Importantly, the effect of remittances differs in sign between banks' foreign currency deposits and loans, giving rise to a mismatch between the two: raising the holdings of loan and reducing those of deposits. These results hold when we address the potential endogeneity of 
remittances by using instrumental variables, when we consider alternative regression specifications and alternative measures of remittances. In each case, the economic size of the effects is non-trivial.

Overall, then, this paper contributes to our understanding of how remittances affect the holdings of deposits and loans in different currencies and to our awareness of the underlying mechanisms behind its asymmetric impact.

\section{References}

Abdih, Yasser, Ralph Chami, Jihad Dagher, and Peter Montiel. 2010. "Remittances and Institutions: Are Remittances a Curse?” World Development 40 (4): 657-666.

Acosta, Pablo, Cesar Calderon, Pablo Fajnzylber, and Humberto Lopez. 2008. "What is the Impact of International Remittances on Poverty and Inequality in Latin America?" World Development 36 (1): 89-114.

Adams Jr., Richard H., and John Page. 2005. "Do International Migration and Remittances Reduce Poverty in Developing Countries?” World Development 33 (10): 1645-69.

Adams, Richard H. 2009. "The Determinants of International Remittances in Developing Countries." World Development 37 (1): 93-103.

Aggarwal, Reena, Asli Demirguc-Kunt, and Maria Soledad Martinez Perìa. 2011. "Do Remittances Promote Financial Development?” Journal of Development Economics 96 (2): 255-64.

Arteta, Carlos. 2005. "Exchange Rate Regimes and Financial Dollarization: Does Flexibility Reduce Bank Currency Mismatches?” B.E. Topics in Macroeconomics 5 (1): 1226-1226.

Balli, Faruk, and Faisal Rana. 2015. "Determinants of Risk Sharing through Remittances.” Journal of Banking and Finance 55: 107-116.

Barajas, Adolfo, and Armando Morales Bueno. 2003. "Dollarization of Liabilities: Beyond the Usual Suspects.” IMF Working Paper.

Barajas, Adolfo, Ralph Chami, Connel Fullenkamp, Michael Gapen, and Peter Montiel. 2009. “Do Workers’ Remittances Promote Economic Growth?” IMF Working Paper.

Basso, Henrique S., Oscar Calvo-Gonzalez, and Marius Jurgilas. 2011. "Financial Dollarization: The Role of Foreign-Owned Banks and Interest Rates.” Journal of Banking \& Finance 35 (4): 794-806.

Benhima, Kenza. 2011. "Exchange Rate Volatility and Productivity Growth: The Role of Liability Dollarization.” Open Economies Review 23 (3): 501-29.

Blackburn, Keith, Niloy Bose, and Salvatore Capasso. 2005. "Financial Development, 
Financing Choice and Economic Growth.” Review of Development Economics 9 (2): 13549.

Bose, Niloy, Jill A. Holman, and Kyriakos C. Neanidis. 2007. "The Optimal Public Expenditure Financing Policy: Does the Level of Economic Development Matter?" Economic Inquiry 45 (3). Blackwell Publishing Inc: 433-52.

Catrinescu, Natalia, Miguel Leon-Ledesma, Matloob Piracha, and Bryce Quillin. 2009. “Remittances, Institutions, and Economic Growth.” World Development 37 (1): 81-92.

Clarke, GRG, and S Wallsten. 2003. "Do Remittances Act like Insurance? Evidence from a Natural Disaster in Jamaica."

Combes, Jean Louis, and Christian Ebeke. 2011. "Remittances and Household Consumption Instability in Developing Countries.” World Development 39 (7): 1076-89.

Cooray, Arusha. 2012. "Migrant Remittances, Financial Sector Development and the Government Ownership of Banks: Evidence from a Group of non-OECD Economies." Journal of International Financial Markets, Institutions \& Money 22: 936-957.

Cox, Donald, Zekeriya Eser, and Emmanuel Jimenez. 1998. "Motives for Private Transfers over the Life Cycle: An Analytical Framework and Evidence for Peru." Journal of Development Economics 55 (1): 57-80.

Cox-Edwards, Alejandra, and Manuelita Ureta. 2003. "International Migration, Remittances, and Schooling: Evidence from El Salvador.” Journal of Development Economics 72 (2): 429-61.

Craig, Ben, and Christopher J. Waller. 2004. "Dollarization and Currency Exchange." Journal of Monetary Economics 51 (4): 671-89.

Demirgüç-Kunt, Asli, Ernesto López Córdova, María Soledad Martínez Pería, and Christopher Woodruff. 2011. "Remittances and Banking Sector Breadth and Depth: Evidence from Mexico.” Journal of Development Economics 95: 229-241.

Fafchamps, Marcel, and Susan Lund. 2003. "Risk-Sharing Networks in Rural Philippines." Journal of Development Economics 71 (2): 261-87.

Faini, Riccardo. 1994. "Workers Remittances and the Real Exchange Rate - A Quantitative Framework." Journal of Population Economics 7 (2): 235-45.

Firdmuc, J., Hake, M., Stix, H., 2013. “Households' Foreign Currency Borrowing in Central and Eastern Europe.” Journal of Banking and Finance 37, 1880-1897.

Fullenkamp, Connel, Thomas Cosimano, Michael Gapen, Ralph Chami, Peter Montiel, and Adolfo Barajas. 2008. "Macroeconomic Consequences of Remittances.” 259. Occasional Papers. Washington, D.C.: International Monetary Fund. 
Girton, Lance, and Don Roper. 1981. "Theory and Implications of Currency Substitution." Journal of Money, Credit \& Banking 13 (1): 12-30.

Giuliano, Paola, and Marta Ruiz-Arranz. 2009. "Remittances, Financial Development, and Growth.” Journal of Development Economics 90: 144-152.

Holman, Jill A., and Kyriakos C. Neanidis. 2006. "Financing Government Expenditures in an Open Economy." Journal of Economic Dynamics and Control 30 (8): 1315-37.

Honig, Adam. 2009. "Dollarization, Exchange Rate Regimes and Government Quality." Journal of International Money and Finance 28 (2): 198-214.

Ize, Alain, and Eduardo Levy Yeyati. 2003. "Financial Dollarization.” Journal of International Economics 59 (2): 323-47.

Kishor, Narayan K., and Kyriakos C. Neanidis. 2015. "What Is Driving Financial Dollarization in Transition Economies? A Dynamic Factor Analysis.” Macroeconomic Dynamics 19 (04): 816-35.

Kleibergen, Frank, and Richard Paap. 2006. "Generalized Reduced Rank Tests Using the Singular Value Decomposition.” Journal of Econometrics 133 (1): 97-126.

Kochar, Anjini. 1999. "Smoothing Consumption by Smoothing Income: Hours-of-Work Responses to Idiosyncratic Agricultural Shocks in Rural India.” Review of Economics and Statistics 81 (1): 50-61.

Lane, Philip R., and Gian Maria Milesi-Ferretti. 2007. "The External Wealth of Nations Mark II: Revised and Extended Estimates of Foreign Assets and Liabilities, 1970-2004.” Journal of International Economics 73 (2): 223-50.

Li, Victor E. 1995. "The Optimal Taxation of Fiat Money in Search Equilibrium." International Economic Review 36 (4).: 927-42.

Lin, Shu, and Haichun Ye. 2013. "Does Inflation Targeting Help Reduce Financial Dollarization?" Journal of Money, Credit and Banking 45 (7): 1253-74.

Luca, Alina, and Iva Petrova. 2008. "What Drives Credit Dollarization in Transition Economies?" Journal of Banking \& Finance 32 (5): 858-69.

Lucas, Robert E. B., and Oded Stark. 1985. "Motivations to Remit: Evidence from Botswana." Journal of Political Economy.

Miles, MA. 1978. "Currency Substitution, Flexible Exchange Rates, and Monetary Independence." The American Economic Review 68 (3): 428-36.

Mishra, Ajit. 2010. "Persistence of Corruption: Some Theoretical Perspectives." World Development 34 (2): 349-58.

Neanidis, Kyriakos C. 2010. "Financial Dollarization and European Union Membership." 
International Finance 13 (2): 257-82.

Neanidis, Kyriakos C., and Christos S. Savva. 2009. "Financial Dollarization: Short-Run Determinants in Transition Economies.” Journal of Banking \& Finance 33 (10): 1860-73.

Nicoló, Gianni De, Patrick Honohan, and Alain Ize. 2005. "Dollarization of Bank Deposits: Causes and Consequences.” Journal of Banking \& Finance 29 (7): 1697-1727.

Paxson, C. H. 1992. "Using Weather Variability to Estimate the Response of Savings to Transitory Income in Thailand." American Economic Review.

Rapoport, Hillel, and F Docquier. 2006. "The Economics of Migrants' Remittances." In Handbook of the Economics of Giving, Altruism, edited by L. A. Gerard-Varet, S. C. Kolm, and J. Mercier-Ythier. Elsevier North Holland.

Ratha, Dilip. 2003. "Workers 'Remittances: An Important and Stable Source of External Development Finance.” In Global Development Finance 2003: Striving for Stability in Development Finance., 157-75. Washington, DC: International Monetary Fund.

Rennhack, Robert, and Masahiro Nozaki. 2006. "Financial Dollarization in Latin America." IMF Working Paper. Springer.

Rosenzweig, Mark R., and Oded Stark. 1989. "Consumption Smoothing, Migration, and Marriage: Evidence from Rural India.” Journal of Political Economy 97 (4): 905.

Rosenzweig, Mark R., and Kenneth I. Wolpin. 1993. "Credit Market Constraints, Consumption Smoothing, and the Accumulation of Durable Production Assets in Low-Income Countries: Investments in Bullocks in India.” Journal of Political Economy 101 (2): 223.

Savastano, M., 1996. "Dollarization in Latin America: Recent Evidence and Some Policy Issues.” IMF Working Paper 96/4.

Thomas, Lee R. 1985. "Portfolio Theory and Currency Substitution." Journal of Money, Credit and Banking 17 (3). [Wiley, Ohio State University Press]: 347-57.

Townsend, Robert M. 1994. "Risk and Insurance in Village India." Econometrica 62 (3): 53991.

Udry, Christopher. 1994. "Risk and Insurance in a Rural Credit Market: An Empirical Investigation in Northern Nigeria." The Review of Economic Studies 61 (3): 495-526.

Vieira, Fabricio A C, Marcio Holland, and Marco F. Resende. 2012. "Financial Dollarization and Systemic Risks: New Empirical Evidence." Journal of International Money and Finance 31 (6): 1695-1714.

Yang, Dean. 2008. "Coping with Disaster: The Impact of Hurricanes on International Financial Flows, 1970-2002.” The B.E. Journal of Economic Analysis \& Policy 8 (1): 1970-2002. Yang, Dean, and HwaJung J. Choi. 2007. “Are Remittances Insurance? Evidence from Rainfall 
Shocks in the Philippines." World Bank Economic Review 21 (2): 219-48.

Yeyati, Eduardo Levy. 2006. "Financial Dollarization: Evaluating the Consequences." Economic Policy, no. January: 61-118. 


\section{Appendix}

\section{Proof of $0<\mathbf{q}<\mathbf{1}$}

The restriction $R_{H}>r>R_{L}$ implies that the denominator of equation (7) is positive, that is, $\left(R_{H}-r\right)\left(r-R_{L}\right)>0$. Equation (7) then implies that $\mathrm{q}>0$ requires $(1-\mu)\left(r-R_{L}\right) R_{H}>\mu\left(R_{H}-r\right) R_{L}$, which,

in turn, holds for values of $\mu<\frac{r-R_{L}}{R_{H}-R_{L}} \frac{R_{H}}{r}$, setting an upper bound for $\mu$. Similarly, equation (7) implies that $\mathrm{q}<1$ requires $(1-\mu)\left(r-R_{L}\right) R_{H}-\mu\left(R_{H}-r\right) R_{L}<\left(R_{H}-r\right)\left(r-R_{L}\right)$, which, in turn, holds for values of $\mu>\frac{r-R_{L}}{R_{H}-R_{L}}$, setting a lower bound for $\mu$. Putting these results together a $q \in(0,1)$ requires $\frac{r-R_{L}}{R_{H}-R_{L}}<\mu<\frac{r-R_{L}}{R_{H}-R_{L}} \frac{R_{H}}{r}$.

\section{Proof of Proposition 1}

Using equation (8) and the restriction $R_{H}>r>R_{L}$, or equivalently $i>i *-S_{f}>i-S_{h}$, one can show that

$$
\begin{aligned}
& \frac{\partial q}{\partial \mu}=-\frac{\left(i^{*}-S_{f}\right) S_{h}}{\left(i-i^{*}+S_{f}\right)\left(i^{*}-S_{f}-i+S_{h}\right)}<0, \\
& \frac{\partial q}{\partial i}=-\frac{\left(i^{*}-S_{f}\right)\left[\left(i^{*}-S_{f}-i+(1-\mu) S_{h}\right)^{2}+\mu(1-\mu) S_{h}^{2}\right]}{\left\{\left(i-i^{*}+S_{f}\right)\left(i^{*}-S_{f}-i+S_{h}\right)\right\}^{2}}<0, \\
& \frac{\partial q}{\partial i^{*}}=\frac{\left(i^{*}-S_{f}-i+S_{h}\right)^{2} i+\mu S_{h}\left[i-\left(i^{*}-S_{f}\right)\right]\left[i+\left(i^{*}-S_{f}\right)\right]}{\left\{\left(i-i^{*}+S_{f}\right)\left(i^{*}-S_{f}-i+S_{h}\right)\right\}^{2}}>0 .
\end{aligned}
$$

\section{Proof of Proposition 2}

Using equation (10) one can show that

$$
\begin{aligned}
& \frac{\partial z}{\partial \mu}=\frac{\left(1+i^{*}-S_{f}\right) S_{h}(1-\alpha)}{\left\{\left(1+i^{*}-S_{f}\right) \alpha+\left[1+\gamma i-(1-\mu) S_{h}\right](1-\alpha)\right\}^{2}}>0, \\
& \frac{\partial z}{\partial i}=\frac{\left(1+i^{*}-S_{f}\right) \alpha \gamma(1-\alpha)}{\left\{\left(1+i^{*}-S_{f}\right) \alpha+\left[1+\gamma i-(1-\mu) S_{h}\right](1-\alpha)\right\}^{2}}>0, \\
& \frac{\partial z}{\partial i^{*}}=-\frac{\left[1+\gamma i-(1-\mu) S_{h}\right] \alpha \gamma(1-\alpha)}{\left\{\left(1+i^{*}-S_{f}\right) \alpha+\left[1+\gamma i-(1-\mu) S_{h}\right](1-\alpha)\right\}^{2}}<0 .
\end{aligned}
$$




\section{Proof of Proposition 3}

Putting together the proofs of Proposition 1 and 2, one can show that since $\partial q / \partial i<0$ and $\partial q / \partial i^{*}>0$, then $\partial q / \partial\left(i / i^{*}\right)<0$, proving the first part of Proposition 3. Similarly, since $\partial z / \partial i>0$ and $\partial z / \partial i^{*}<0$, it follows that $\partial z / \partial\left(i / i^{*}\right)>0$, proving the second part of Proposition 3 .

\section{Table A: Variable Definitions and Sources}

Variable Definition [source]

Dependent variables

Foreign currency deposits

Foreign currency denominated deposits to total deposits of residents held in resident banks [IMF, International Financial Statistics (IFS) and National Central Banks (NCB)]

Foreign currency loans Foreign currency denominated credit to total credits of residents issued by resident Control variables

Remittances per capita banks [IFS and NCB]

High FCD dummy

High FCL dummy

Net foreign assets

Restrictions

MVP dollar share

Inflation

Depreciation

Index of international financial integration

EU dummy
Remittances in US dollars scaled by recipient country population. Remittances represent the sum of remittances and worker's compensation, except for Albania (remittances), the Czech Rep. (worker's compensation), Georgia (remittances), Latvia (worker's compensation) and Moldova (remittances) [NCB, based on Balance of Payments statistics]

Dummy variable that takes the value of 1 if the share of foreign currency deposits in total deposits exceeds 50 percent and 0 otherwise [Author's calculation]

Dummy variable that takes the value of 1 if the share of foreign currency loans in total loans exceeds 50 percent and 0 otherwise [Author's calculation]

The ratio of commercial banks' and other depository corporations' foreign assets minus external liabilities to total domestic deposits [IFS and NCB]

Dummy variable that takes the value of 1 when there are restrictions on residents holdings of onshore foreign currency deposits (loans) and 0 otherwise [AREAR, IMF]

$[\operatorname{Var}($ Inflation $)+\operatorname{Cov}($ Inflation, $\Delta($ Real exchange rate $))] /[\operatorname{Var}($ Inflation $)+\operatorname{Var}(\Delta($ Real exchange rate $)+\Delta \operatorname{Cov}($ Inflation, $\mathrm{D}$ (Real exchange rate) $)$ ] as constructed by Ize and Levy-Yeyati (2003). Following Basso et al. (2011), we compute MVP based on all historical information up to the observation point [Author's calculation]

Logarithmic difference of the Consumer Price Index [IFS]

Logarithmic difference of the nominal official exchange rate (national currency/USD) [IFS]

Volume-based measure of international financial integration as constructed by Lane and Milesi-Ferretti (2007): (total external assets + total external liabilities) / GDP [updated and extended version of the External Wealth of Nations Mark II database developed by Lane and Milesi-Ferretti (2007)]

Dummy variable that takes the value of 1 during the dates of (i) the beginning of the EU accession negotiations, (ii) the end of the negotiation process, and (iii) after full membership to the EU, and 0 otherwise. See below for details on each of these periods and the countries involved [Author's calculation] 
Instruments

Regional remittances per capita

Stock of migrants per capita

Robustness variables

Start of EU accession process

Decision to join EU

EU membership

Dummy for forward market liberalization

Index of asymmetry of exchange

rate movements

Index of exchange rate

intervention

Corruption

Real per capita remittances

Remittances as fraction of total deposits (total loans)

Remittances as fraction of GDP
Remittances per capita of all other recipient countries located in the region [Author's calculation]

Sum of outward migrants from each labour-exporting country residing in the OECD (and selected non-OECD) member countries, divided by the total population of the country of origin [International Migration Dataset, OECD]

Dummy variable that takes the value of 1 during the dates of the beginning of the EU accession negotiations and before the end of the negotiation process and 0 otherwise. The beginning of negotiations started on March 1998 for the Czech Rep., Estonia, Hungary, Latvia, Lithuania, Poland, Slovak Rep., and Slovenia; on December 1999 for Bulgaria; on October 2005 for Turkey

[http://europa.eu/abc/history]

Dummy variable that takes the value of 1 during the dates decided by the EU for negotiating countries to join the EU and before full EU membership and 0 otherwise. The negotiations ended on December 2002 for the Czech Rep., Estonia, Hungary, Latvia, Lithuania, Poland, Slovak Rep., and Slovenia; on April 2005 for Bulgaria [http://europa.eu/abc/history]

Dummy variable that takes the value of 1 after full membership to the EU and 0 otherwise. Full membership started on May 2004 for the Czech Rep., Estonia, Hungary, Latvia, Lithuania, Poland, Slovak Rep., and Slovenia; on January 2007 for Bulgaria [http://europa.eu/abc/history]

Dummy variable that takes the value of 1 if there exists a functional forward market and 0 otherwise [Luca and Petrova (2007) and AREAR, IMF]

Index of asymmetry of exchange rate movements as constructed by Rennhack and Nozaki (2006): assigning a value of 0 in months of currency appreciation and 1 in months of currency depreciation [Author's calculation]

Indicator of exchange rate intervention as constructed by Barajas and Morales (2003): $(\Delta \text { int_res/M2 })^{2} /\left((\text { First Difference(Exchange Rate)/Exchange Rate })^{2}+\right.$ $\left.(\Delta \text { int_res } / \mathrm{M} 2)^{2}\right)$ [Author's calculation drawn from IFS]

Inverse of corruption perception index proxying for the control or absence of corruption [Transparency International] Remittances per capita deflated by US CPI [Author's calculation]

Remittances scaled by recipient country total deposits (total loans), all expressed in millions of US dollars [Author's calculation]

Remittances scaled by recipient country GDP, both expressed in millions of US dollars [Author's calculation] 
Table 1: Summary Statistics

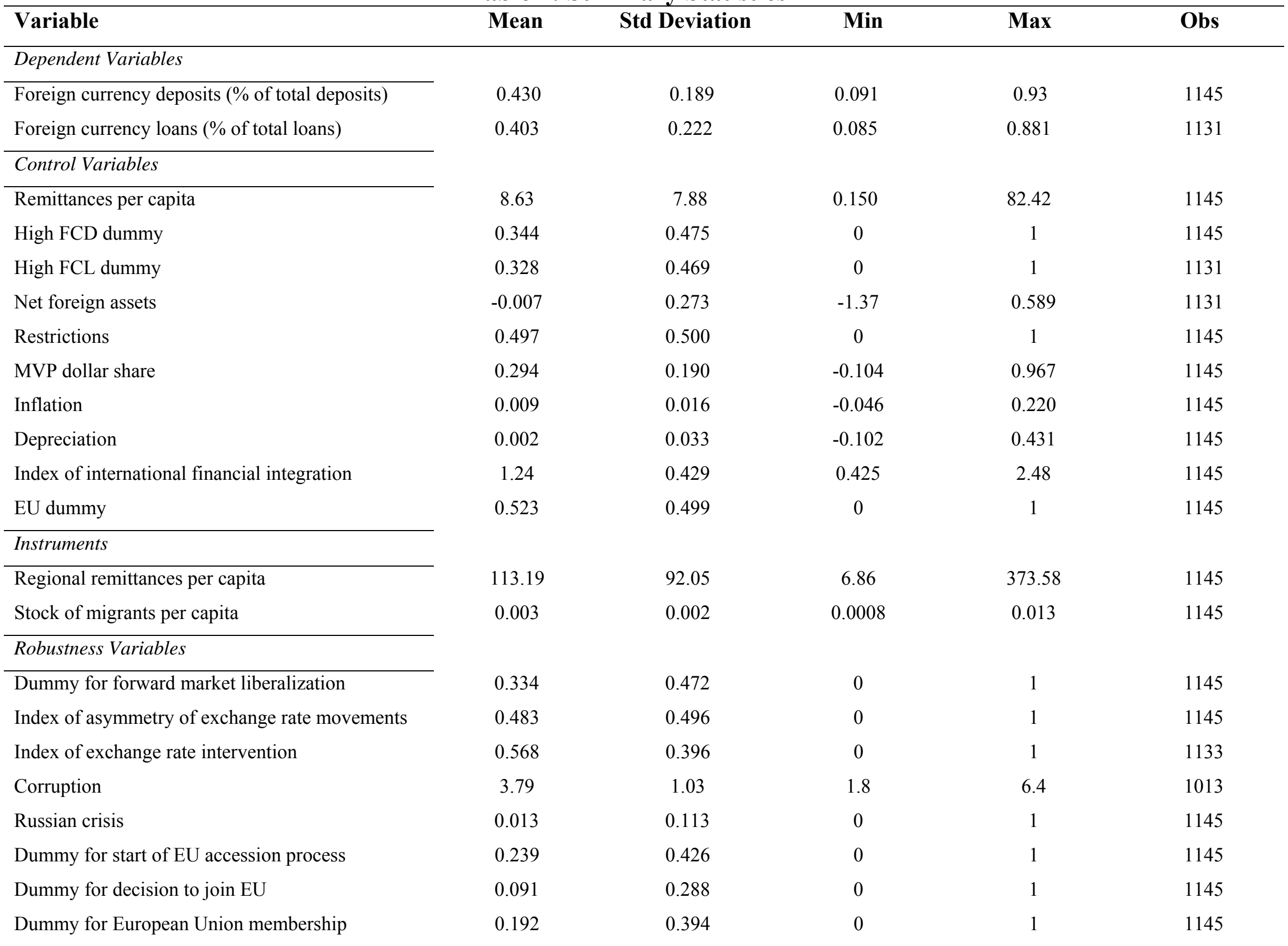

Notes: For definitions and sources see Appendix Table A. 
Figure 1: Remittances per Capita

Remittances per capita

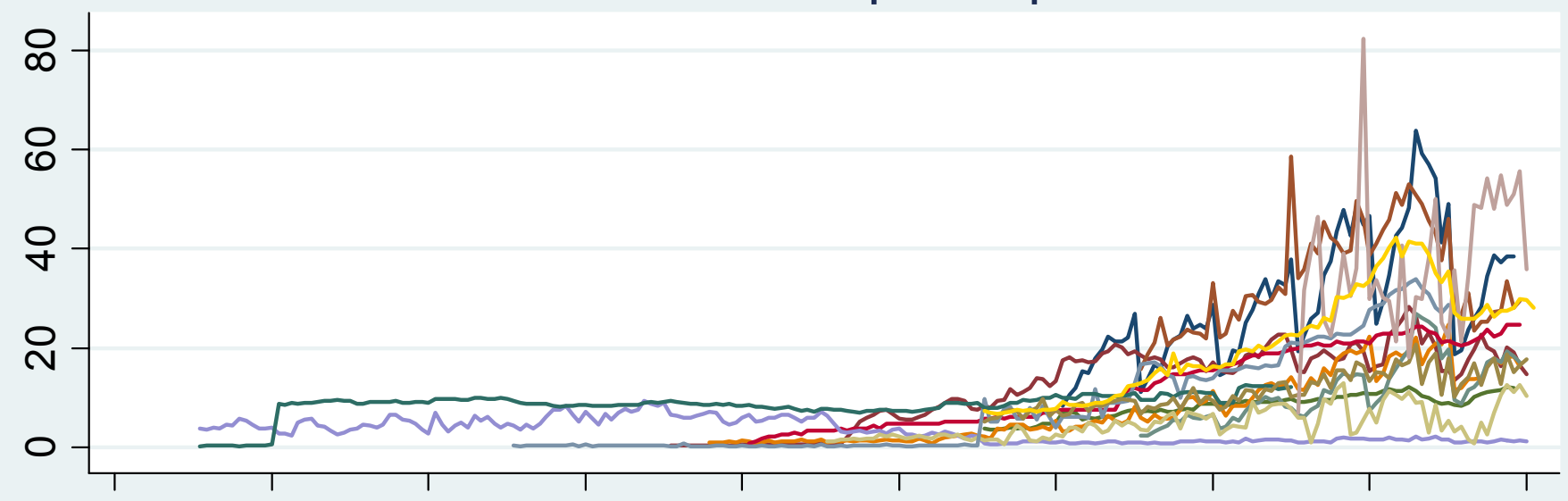

1992m1 1994m1 1996m1 1998m1 2000m1 2002m1 2004m1 2006m1 2008m1 2010m1 datevar

\begin{tabular}{|ll|}
\hline Armenia & Bulgaria \\
Czech Rep & Georgia \\
Kyrgyz Rep & Latvia \\
Turkey & Lithuania \\
Romania & Slovak Rep \\
Slovenia & Macedonia, FYR \\
Serbia & Moldova \\
\hline
\end{tabular}


Table 2: Foreign currency deposits and loans with different estimation techniques

\begin{tabular}{|c|c|c|c|c|c|c|c|c|}
\hline \multirow{2}{*}{$\begin{array}{l}\text { Estimator } \rightarrow \\
\text { Dependent variable } \rightarrow\end{array}$} & \multicolumn{2}{|c|}{ OLS } & \multicolumn{2}{|c|}{ FGLS } & \multicolumn{2}{|c|}{ FE } & \multicolumn{2}{|c|}{ IV-GMM } \\
\hline & $\begin{array}{c}\text { FCD } \\
(1)\end{array}$ & $\begin{array}{c}\text { FCL } \\
\text { (2) }\end{array}$ & $\begin{array}{c}\text { FCD } \\
(3)\end{array}$ & $\begin{array}{c}\text { FCL } \\
(4)\end{array}$ & $\begin{array}{c}\text { FCD } \\
(5)\end{array}$ & $\begin{array}{c}\text { FCL } \\
(6)\end{array}$ & $\begin{array}{c}\text { FCD } \\
(7)\end{array}$ & $\begin{array}{c}\text { FCL } \\
(8)\end{array}$ \\
\hline Remittances per capita & $\begin{array}{c}-0.002 * * * \\
(0.0005)\end{array}$ & $\begin{array}{c}-0.001 * * * \\
(0.0005)\end{array}$ & $\begin{array}{c}-0.0008^{* *} \\
(0.0004)\end{array}$ & $\begin{array}{c}-0.0005^{*} \\
(0.003)\end{array}$ & $\begin{array}{c}-0.003 * * * \\
(0.0002)\end{array}$ & $\begin{array}{l}0.0006^{*} \\
(0.0003)\end{array}$ & $\begin{array}{c}-0.007 * * \\
(0.003)\end{array}$ & $\begin{array}{c}0.004 * * * \\
(0.001)\end{array}$ \\
\hline Foreign currency deposits & & $\begin{array}{c}0.534 * * * \\
(0.024)\end{array}$ & & $\begin{array}{c}0.519 * * * \\
(0.015)\end{array}$ & & $\begin{array}{c}0.956 * * * \\
(0.034)\end{array}$ & & $\begin{array}{c}0.564 * * * \\
(0.123)\end{array}$ \\
\hline Net foreign assets & & $\begin{array}{c}-0.164 * * * \\
(0.013)\end{array}$ & & $\begin{array}{c}-0.172 * * * \\
(0.008)\end{array}$ & & $\begin{array}{c}-0.199 * * * \\
(0.014)\end{array}$ & & $\begin{array}{l}-0.102 * \\
(0.060)\end{array}$ \\
\hline High FCL dummy & & $\begin{array}{c}0.211^{* * *} \\
(0.009)\end{array}$ & & $\begin{array}{c}0.196^{* * *} \\
(0.006)\end{array}$ & & $\begin{array}{c}0.092 * * * \\
(0.008)\end{array}$ & & $\begin{array}{c}0.257 * * * \\
(0.042)\end{array}$ \\
\hline High FCD dummy & $\begin{array}{c}0.192 * * * \\
(0.006)\end{array}$ & & $\begin{array}{c}0.173 * * * \\
(0.006)\end{array}$ & & $\begin{array}{c}0.070 * * * \\
(0.004)\end{array}$ & & $\begin{array}{c}0.174 * * * \\
(0.039)\end{array}$ & \\
\hline Restrictions & $\begin{array}{c}-0.032 * * * \\
(0.006)\end{array}$ & $\begin{array}{c}-0.031 * * * \\
(0.007)\end{array}$ & $\begin{array}{c}-0.015 * * * \\
(0.005)\end{array}$ & $\begin{array}{c}-0.015 * * * \\
(0.003)\end{array}$ & $\begin{array}{c}0.003 \\
(0.003)\end{array}$ & $\begin{array}{c}-0.032 * * * \\
(0.004)\end{array}$ & $\begin{array}{l}-0.040 \\
(0.029)\end{array}$ & $\begin{array}{c}0.008 \\
(0.019)\end{array}$ \\
\hline MVP dollar share & $\begin{array}{c}0.357 * * * \\
(0.015)\end{array}$ & $\begin{array}{c}0.244 * * * \\
(0.016)\end{array}$ & $\begin{array}{c}0.289 * * * \\
(0.013)\end{array}$ & $\begin{array}{c}0.244 * * * \\
(0.012)\end{array}$ & $\begin{array}{c}0.308 * * * \\
(0.017)\end{array}$ & $\begin{array}{c}-0.036 \\
(0.023)\end{array}$ & $\begin{array}{c}0.376 * * * \\
(0.088)\end{array}$ & $\begin{array}{c}0.167 * * \\
(0.079)\end{array}$ \\
\hline Inflation & $\begin{array}{c}-0.344 * * \\
(0.170)\end{array}$ & $\begin{array}{l}1.20 * * * \\
(0.202)\end{array}$ & $\begin{array}{c}-0.060 \\
(0.159)\end{array}$ & $\begin{array}{c}0.644 * * * \\
(0.152)\end{array}$ & $\begin{array}{c}0.138 \\
(0.088)\end{array}$ & $\begin{array}{c}0.918 * * * \\
(0.124)\end{array}$ & $\begin{array}{l}-0.526 \\
(0.381)\end{array}$ & $\begin{array}{l}1.26^{* *} \\
(0.521)\end{array}$ \\
\hline Depreciation & $\begin{array}{l}0.150 * \\
(0.077)\end{array}$ & $\begin{array}{l}0.168 * \\
(0.088)\end{array}$ & $\begin{array}{l}0.128 * \\
(0.071)\end{array}$ & $\begin{array}{c}0.118 * * \\
(0.054)\end{array}$ & $\begin{array}{c}0.078 * * \\
(0.036)\end{array}$ & $\begin{array}{c}0.177 * * * \\
(0.047)\end{array}$ & $\begin{array}{c}0.105 * * * \\
(0.039)\end{array}$ & $\begin{array}{c}0.186 * * \\
(0.076)\end{array}$ \\
\hline International financial integration & $\begin{array}{c}0.074 * * * \\
(0.010)\end{array}$ & $\begin{array}{c}0.065^{* * *} \\
(0.008)\end{array}$ & $\begin{array}{c}0.074 * * * \\
(0.007)\end{array}$ & $\begin{array}{c}0.068 * * * \\
(0.006)\end{array}$ & $\begin{array}{c}0.036 * * * \\
(0.005)\end{array}$ & $\begin{array}{c}0.043^{* * *} * \\
(0.009)\end{array}$ & $\begin{array}{c}0.130 * * \\
(0.065)\end{array}$ & $\begin{array}{c}0.044 \\
(0.031)\end{array}$ \\
\hline EU dummy & $\begin{array}{c}-0.199 * * * \\
(0.009)\end{array}$ & $\begin{array}{c}-0.014 \\
(0.009)\end{array}$ & $\begin{array}{c}-0.161 * * * \\
(0.007)\end{array}$ & $\begin{array}{c}-0.016 * * * \\
(0.006)\end{array}$ & $\begin{array}{c}-0.061 * * * \\
(0.005)\end{array}$ & $\begin{array}{c}-0.046 * * * \\
(0.006)\end{array}$ & $\begin{array}{c}-0.259 * * * \\
(0.046)\end{array}$ & $\begin{array}{c}0.042 \\
(0.035)\end{array}$ \\
\hline Countries / Obs & $13 / 1145$ & $14 / 1131$ & $13 / 1145$ & $14 / 1131$ & $13 / 1145$ & $14 / 1131$ & $13 / 1145$ & $14 / 1131$ \\
\hline R-square (centered) & 0.758 & 0.885 & & & 0.550 & 0.670 & 0.727 & 0.851 \\
\hline LM test (p-value) & & & & & & & 0.050 & 0.028 \\
\hline F test & & & & & & & 8.62 & 49.94 \\
\hline Hansen J-test (p-value) & & & & & & & 0.286 & 0.179 \\
\hline
\end{tabular}

First-stage results

\section{Dependent variable: Remittances}

per capita

Regional remittances per capita

Stock of migrants per capita

R-square (centered)

(a)

F test

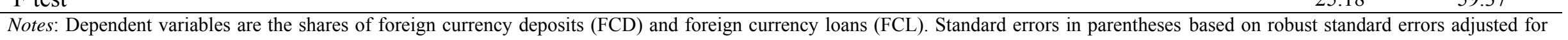

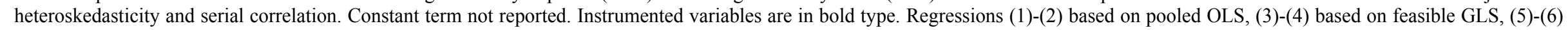




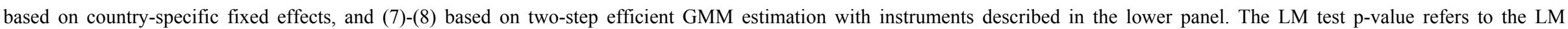

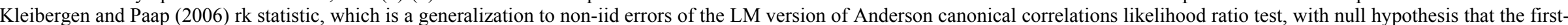

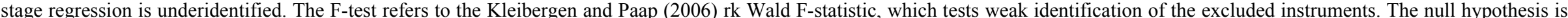

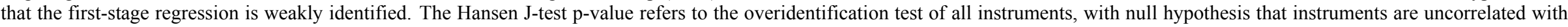

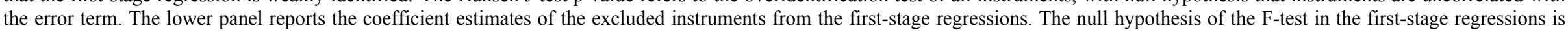
that the coefficients on the excluded instruments equal zero. ${ }^{* * *}, * *, *$ denote significance at the $1 \%, 5 \%, 10 \%$ level, respectively. 
Table 3: Foreign currency deposits and loans with additional controls

\begin{tabular}{|c|c|c|c|c|c|c|c|c|c|c|}
\hline Dependent variable $\rightarrow$ & $\begin{array}{c}\text { FCD } \\
(1)\end{array}$ & $\begin{array}{c}\text { FCL } \\
(2) \\
\end{array}$ & $\begin{array}{c}\text { FCD } \\
(3) \\
\end{array}$ & $\begin{array}{c}\text { FCL } \\
(4) \\
\end{array}$ & $\begin{array}{c}\text { FCD } \\
(5) \\
\end{array}$ & $\begin{array}{c}\text { FCL } \\
(6) \\
\end{array}$ & $\begin{array}{c}\text { FCD } \\
(7) \\
\end{array}$ & $\begin{array}{c}\text { FCL } \\
(8) \\
\end{array}$ & $\begin{array}{l}\text { FCD } \\
(9) \\
\end{array}$ & $\begin{array}{l}\text { FCL } \\
(10)\end{array}$ \\
\hline Remittances per capita & $\begin{array}{c}-0.006 * * \\
(0.003)\end{array}$ & $\begin{array}{c}0.003 * * \\
(0.001)\end{array}$ & $\begin{array}{c}-0.007 * * \\
(0.003)\end{array}$ & $\begin{array}{l}0.004 * * * \\
(0.001)\end{array}$ & $\begin{array}{c}-0.007 * * \\
(0.03)\end{array}$ & $\begin{array}{c}0.004 * * * \\
(0.001)\end{array}$ & $\begin{array}{c}-0.006 * * \\
(0.003)\end{array}$ & $\begin{array}{c}0.003 * * * \\
(0.001)\end{array}$ & $\begin{array}{c}-0.009 * * * \\
(0.003)\end{array}$ & $\begin{array}{c}0.001 * \\
(0.0005)\end{array}$ \\
\hline Foreign currency deposits & & $\begin{array}{l}0.727 * * * \\
(0.119)\end{array}$ & & $\begin{array}{l}0.525 * * * \\
(0.113)\end{array}$ & & $\begin{array}{l}0.566^{* * * *} \\
(0.122)\end{array}$ & & $\begin{array}{l}0.602 * * * \\
(0.120)\end{array}$ & & $\begin{array}{c}0.420 * * * \\
(0.108)\end{array}$ \\
\hline Net foreign assets & & $\begin{array}{l}-0.078 \\
(0.063)\end{array}$ & & $\begin{array}{l}-0.107 * * \\
(0.054)\end{array}$ & & $\begin{array}{l}-0.104^{*} \\
(0.061)\end{array}$ & & $\begin{array}{c}-0.124 * * \\
(0.060)\end{array}$ & & $\begin{array}{c}-0.181 * * * \\
(0.044)\end{array}$ \\
\hline High FCL dummy & & $\begin{array}{l}0.238 * * * \\
(0.040)\end{array}$ & & $\begin{array}{l}0.265^{* * *} \\
(0.039)\end{array}$ & & $\begin{array}{l}0.257 * * * \\
(0.042)\end{array}$ & & $\begin{array}{c}0.243 * * * \\
(0.040)\end{array}$ & & $\begin{array}{c}0.200 * * * \\
(0.026)\end{array}$ \\
\hline High FCD dummy & $\begin{array}{c}0.153 * * * \\
(0.045)\end{array}$ & & $\begin{array}{c}0.179^{* * *} \\
(0.040)\end{array}$ & & $\begin{array}{c}0.174 * * * \\
(0.039)\end{array}$ & & $\begin{array}{c}0.183 * * * \\
(0.040)\end{array}$ & & $\begin{array}{c}0.132 * * * \\
(0.029)\end{array}$ & \\
\hline Restrictions & $\begin{array}{c}-0.065^{* *} \\
(0.025)\end{array}$ & $\begin{array}{c}0.019 \\
(0.022)\end{array}$ & $\begin{array}{c}-0.041 \\
(0.029)\end{array}$ & $\begin{array}{c}0.002 \\
(0.018)\end{array}$ & $\begin{array}{l}-0.039 \\
(0.029)\end{array}$ & $\begin{array}{c}0.008 \\
(0.019)\end{array}$ & $\begin{array}{l}-0.041 \\
(0.026)\end{array}$ & $\begin{array}{c}0.004 \\
(0.017)\end{array}$ & $\begin{array}{l}-0.041 \\
(0.036)\end{array}$ & $\begin{array}{l}-0.011 \\
(0.017)\end{array}$ \\
\hline MVP dollar share & $\begin{array}{c}0.324 * * * \\
(0.089)\end{array}$ & $\begin{array}{c}0.161 * * \\
(0.073)\end{array}$ & $\begin{array}{c}0.413 * * * \\
(0.105)\end{array}$ & $\begin{array}{l}0.160 * * \\
(0.073)\end{array}$ & $\begin{array}{c}0.377 * * * \\
(0.088)\end{array}$ & $\begin{array}{c}0.167 * * \\
(0.079)\end{array}$ & $\begin{array}{c}0.375 * * * \\
(0.063)\end{array}$ & $\begin{array}{c}0.173 * * \\
(0.069)\end{array}$ & $\begin{array}{c}0.414 * * * \\
(0.094)\end{array}$ & $\begin{array}{c}0.283 * * * \\
(0.056)\end{array}$ \\
\hline Inflation & $\begin{array}{c}-0.466 \\
(0.424)\end{array}$ & $\begin{array}{l}1.20 * * \\
(0.469)\end{array}$ & $\begin{array}{l}-0.569 \\
(0.421)\end{array}$ & $\begin{array}{l}1.09 * * \\
(0.528)\end{array}$ & $\begin{array}{c}-0.536 \\
(0.372)\end{array}$ & $\begin{array}{l}1.26 * * \\
(0.523)\end{array}$ & $\begin{array}{c}-0.719 * * \\
(0.355)\end{array}$ & $\begin{array}{l}1.28 * * \\
(0.501)\end{array}$ & $\begin{array}{c}-0.506 \\
(0.376)\end{array}$ & $\begin{array}{c}0.822 * * \\
(0.321)\end{array}$ \\
\hline Depreciation & $\begin{array}{c}0.116^{* * *} \\
(0.036)\end{array}$ & $\begin{array}{c}0.160 * * \\
(0.069)\end{array}$ & $\begin{array}{c}0.092 * * \\
(0.042)\end{array}$ & $\begin{array}{c}0.156 * * \\
(0.066)\end{array}$ & $\begin{array}{c}0.183 * * \\
(0.073)\end{array}$ & $\begin{array}{c}0.201 \\
(0.141)\end{array}$ & $\begin{array}{l}0.124 * * \\
(0.054)\end{array}$ & $\begin{array}{l}0.135^{*} \\
(0.072)\end{array}$ & $\begin{array}{l}0.135^{*} \\
(0.080)\end{array}$ & $\begin{array}{c}0.273 * * * \\
(0.074)\end{array}$ \\
\hline International financial integration & $\begin{array}{c}0.163 * * * \\
(0.061)\end{array}$ & $\begin{array}{c}0.004 \\
(0.028)\end{array}$ & $\begin{array}{c}0.143 * * \\
(0.063)\end{array}$ & $\begin{array}{l}0.043 * \\
(0.033)\end{array}$ & $\begin{array}{c}0.130 * * \\
(0.065)\end{array}$ & $\begin{array}{c}0.044 \\
(0.031)\end{array}$ & $\begin{array}{c}0.132 * * \\
(0.058)\end{array}$ & $\begin{array}{c}0.045 \\
(0.030)\end{array}$ & $\begin{array}{c}0.170 * * \\
(0.069)\end{array}$ & $\begin{array}{l}0.047 * \\
(0.025)\end{array}$ \\
\hline EU dummy & & & $\begin{array}{c}-0.262 * * * \\
(0.045)\end{array}$ & $\begin{array}{c}0.041 \\
(0.036)\end{array}$ & $\begin{array}{c}-0.259 * * * \\
(0.045)\end{array}$ & $\begin{array}{c}0.042 \\
(0.036)\end{array}$ & $\begin{array}{c}-0.255^{* * *} \\
(0.043)\end{array}$ & $\begin{array}{c}0.045 \\
(0.034)\end{array}$ & $\begin{array}{c}-0.321 * * * \\
(0.072)\end{array}$ & $\begin{array}{c}0.031 \\
(0.035)\end{array}$ \\
\hline Start of EU accession process & $\begin{array}{c}-0.243 * * * \\
(0.042)\end{array}$ & $\begin{array}{c}0.048^{*} \\
(0.029)\end{array}$ & & & & & & & & \\
\hline Decision to join EU & $\begin{array}{c}-0.325 * * * \\
(0.050)\end{array}$ & $\begin{array}{c}0.120 * * * \\
(0.039)\end{array}$ & & & & & & & & \\
\hline European Union membership & $\begin{array}{c}-0.348 * * * \\
(0.043)\end{array}$ & $\begin{array}{c}0.155 * * * \\
(0.050)\end{array}$ & & & & & & & & \\
\hline Forward market liberalization & & & $\begin{array}{c}-0.013 \\
(0.041)\end{array}$ & $\begin{array}{c}-0.028 \\
(0.025)\end{array}$ & & & & & & \\
\hline Asymmetry of exchange rate movement & & & & & $\begin{array}{c}-0.008 \\
(0.005)\end{array}$ & $\begin{array}{l}-0.002 \\
(0.009)\end{array}$ & & & & \\
\hline Exchange rate intervention & & & & & & & $\begin{array}{c}-0.056^{* *} \\
(0.024)\end{array}$ & $\begin{array}{c}0.035 * * \\
(0.014)\end{array}$ & & \\
\hline Corruption & & & & & & & & & $\begin{array}{c}0.006 \\
(0.027)\end{array}$ & $\begin{array}{c}-0.032 * * * \\
(0.008)\end{array}$ \\
\hline Countries / Obs & $13 / 1145$ & $14 / 1131$ & $13 / 1145$ & $14 / 1131$ & $13 / 1145$ & $14 / 1131$ & $13 / 1133$ & $14 / 1119$ & $13 / 1013$ & $14 / 999$ \\
\hline R-square (centered) & 0.742 & 0.872 & 0.718 & 0.859 & 0.726 & 0.851 & 0.748 & 0.861 & 0.714 & 0.876 \\
\hline LM test (p-value) & 0.046 & 0.020 & 0.042 & 0.017 & 0.049 & 0.029 & 0.052 & 0.026 & 0.040 & 0.023 \\
\hline F test & 8.74 & 45.83 & 7.95 & 58.20 & 8.74 & 49.92 & 10.08 & 56.15 & 13.37 & 110.3 \\
\hline
\end{tabular}




\section{Hansen J-test (p-value)}

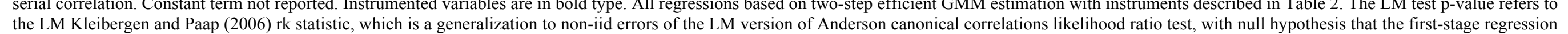

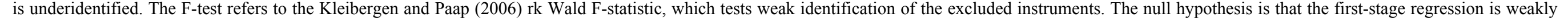

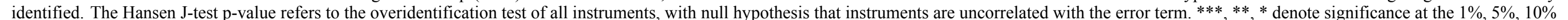
level, respectively. 
Table 4: Foreign currency deposits and loans with different measures of remittances

\begin{tabular}{|c|c|c|c|c|c|c|}
\hline \multirow{2}{*}{$\begin{array}{l}\text { Measure of remittances } \rightarrow \\
\text { Dependent variable } \rightarrow\end{array}$} & \multicolumn{2}{|c|}{$\begin{array}{c}\text { Real per capita } \\
\text { remittances }\end{array}$} & \multirow{2}{*}{$\begin{array}{c}\text { Remittances } \\
\text { \% of deposits } \\
\text { FCD } \\
\text { (3) }\end{array}$} & \multirow{2}{*}{$\begin{array}{c}\text { Remittances } \\
\% \text { of loans } \\
\text { FCL } \\
(4)\end{array}$} & \multicolumn{2}{|c|}{$\begin{array}{c}\text { Remittances } \\
\% \text { of GDP }\end{array}$} \\
\hline & $\begin{array}{c}\text { FCD } \\
(1)\end{array}$ & $\begin{array}{c}\text { FCL } \\
\text { (2) }\end{array}$ & & & $\begin{array}{c}\text { FCD } \\
(5)\end{array}$ & $\begin{array}{c}\text { FCL } \\
(6)\end{array}$ \\
\hline Remittances & $\begin{array}{c}-0.807 * * \\
(0.362)\end{array}$ & $\begin{array}{c}0.448 * * * \\
(0.129)\end{array}$ & $\begin{array}{c}-2.00 * * * \\
(0.737)\end{array}$ & $\begin{array}{l}0.066 * * \\
(0.029)\end{array}$ & $\begin{array}{c}-13.36 * * \\
(6.34)\end{array}$ & $\begin{array}{l}9.67 * * * \\
(3.11)\end{array}$ \\
\hline Foreign currency deposits & & $\begin{array}{c}0.561 * * * \\
(0.125)\end{array}$ & & $\begin{array}{c}0.534 * * * \\
(0.122)\end{array}$ & & $\begin{array}{l}0.578 * * * \\
(0.133)\end{array}$ \\
\hline Net foreign assets & & $\begin{array}{l}-0.095 \\
(0.063)\end{array}$ & & $\begin{array}{c}-0.124 * * \\
(0.049)\end{array}$ & & $\begin{array}{c}-0.164 * * * \\
(0.045)\end{array}$ \\
\hline High FCL dummy & & $\begin{array}{c}0.263 * * * \\
(0.044)\end{array}$ & & $\begin{array}{c}0.226 * * * \\
(0.031)\end{array}$ & & $\begin{array}{c}0.230 * * * \\
(0.036)\end{array}$ \\
\hline High FCD dummy & $\begin{array}{c}0.167 * * * \\
(0.038)\end{array}$ & & $\begin{array}{c}0.221 * * * \\
(0.043)\end{array}$ & & $\begin{array}{c}0.207 * * * \\
(0.044)\end{array}$ & \\
\hline Restrictions & $\begin{array}{l}-0.040 \\
(0.029)\end{array}$ & $\begin{array}{c}0.008 \\
(0.020)\end{array}$ & $\begin{array}{c}-0.059 * * \\
(0.023)\end{array}$ & $\begin{array}{c}-0.018 \\
(0.017)\end{array}$ & $\begin{array}{c}-0.036^{*} \\
(0.021)\end{array}$ & $\begin{array}{c}-0.002 \\
(0.019)\end{array}$ \\
\hline MVP dollar share & $\begin{array}{c}0.384 * * * \\
(0.090)\end{array}$ & $\begin{array}{l}0.162 * * \\
(0.082)\end{array}$ & $\begin{array}{c}0.493 * * * \\
(0.097)\end{array}$ & $\begin{array}{c}0.210 * * * \\
(0.077)\end{array}$ & $\begin{array}{c}0.447 * * * \\
(0.090)\end{array}$ & $\begin{array}{c}0.126 \\
(0.083)\end{array}$ \\
\hline Inflation & $\begin{array}{c}-0.500 \\
(0.368)\end{array}$ & $\begin{array}{l}1.35^{* *} \\
(0.542)\end{array}$ & $\begin{array}{c}-0.997 * * \\
(0.467)\end{array}$ & $\begin{array}{l}1.54 * * * \\
(0.567)\end{array}$ & $\begin{array}{c}-0.627 \\
(0.390)\end{array}$ & $\begin{array}{l}1.30 * * \\
(0.527)\end{array}$ \\
\hline Depreciation & $\begin{array}{c}0.097 * * \\
(0.040)\end{array}$ & $\begin{array}{l}0.194 * * \\
(0.076)\end{array}$ & $\begin{array}{c}0.060 \\
(0.056)\end{array}$ & $\begin{array}{c}0.250 * * * \\
(0.078)\end{array}$ & $\begin{array}{l}0.082 * \\
(0.046)\end{array}$ & $\begin{array}{c}0.237 * * * \\
(0.074)\end{array}$ \\
\hline International financial integration & $\begin{array}{c}0.133 * * \\
(0.067)\end{array}$ & $\begin{array}{c}0.047 \\
(0.031)\end{array}$ & $\begin{array}{c}0.114 * * \\
(0.044)\end{array}$ & $\begin{array}{c}0.077 * * \\
(0.030)\end{array}$ & $\begin{array}{c}0.135 * * * \\
(0.052)\end{array}$ & $\begin{array}{c}0.004 \\
(0.038)\end{array}$ \\
\hline EU dummy & $\begin{array}{c}-0.266^{* * * *} \\
(0.048)\end{array}$ & $\begin{array}{c}0.042 \\
(0.036)\end{array}$ & $\begin{array}{c}-0.303 * * * \\
(0.053)\end{array}$ & $\begin{array}{l}-0.009 \\
(0.032)\end{array}$ & $\begin{array}{c}-0.290 * * * \\
(0.052)\end{array}$ & $\begin{array}{l}0.088^{*} \\
(0.048)\end{array}$ \\
\hline Countries / Obs & $13 / 1145$ & $14 / 1131$ & $13 / 1145$ & $14 / 1078$ & $13 / 1145$ & $14 / 1131$ \\
\hline R-square (centered) & 0.715 & 0.846 & 0.725 & 0.884 & 0.735 & 0.854 \\
\hline LM test (p-value) & 0.079 & 0.050 & 0.055 & 0.450 & 0.033 & 0.024 \\
\hline F test & 6.90 & 32.54 & 13.21 & 9.46 & 8.04 & 10.13 \\
\hline Hansen J-test (p-value) & 0.316 & 0.221 & 0.948 & 0.824 & 0.728 & 0.462 \\
\hline
\end{tabular}

Notes: Dependent variables are the shares of foreign currency deposits (FCD) and foreign currency loans (FCL). Standard errors in parentheses based on robust standard errors adjusted for heteroskedasticity and serial correlation. Constant term not reported. Instrumented variables are in bold type. All regressions based on two-step efficient GMM estimation with instruments described in Table 2 but with the following changes: instead of per capita regional remittances, columns (1)-(2) use real per capita regional remittances, columns (3)-(4) use the ratio of regional remittances to regional deposits and loans, and columns (5)-(6) use the ratio of regional remittances to regional GDP. The LM test p-value refers to the LM Kleibergen and Paap (2006) rk statistic, which is a generalization to non-iid errors of the LM version of Anderson canonical correlations likelihood ratio test, with null hypothesis that the first-stage regression is underidentified. The F-test refers to the Kleibergen and Paap (2006) rk Wald F-statistic, which tests weak identification of the excluded instruments. The null hypothesis is that the first-stage regression is weakly identified. The Hansen J-test p-value refers to the overidentification test of all instruments, with null hypothesis that instruments are uncorrelated with the error term. $* * *, * *, *$ denote significance at the $1 \%, 5 \%, 10 \%$ level, respectively. 